OPEN ACCESS

Edited by:

Maria Luisa Blazquez, Complutense University of Madrid,

Spain

Reviewed by:

Gaurav Saxena,

Babasaheb Bhimrao Ambedkar

University, India

M. Oves,

King Abdulaziz University,

Saudi Arabia

${ }^{*}$ Correspondence:

Jaime Gomez-Bolivar

jagobo@correo.ugr.es

Lynne E. Macaskie

L.E.Macaskie@bham.ac.uk

Specialty section:

This article was submitted to Microbiotechnology, Ecotoxicology

and Bioremediation,

a section of the journal

Frontiers in Microbiology

Received: 26 November 2018

Accepted: 22 May 2019

Published: 20 June 2019

Citation:

Gomez-Bolivar J, Mikheenko IP, Orozco RL, Sharma S, Banerjee D, Walker M, Hand RA, Merroun ML and

Macaskie LE (2019) Synthesis of $\mathrm{Pd} / \mathrm{Ru}$ Bimetallic Nanoparticles by

Escherichia coli and Potential as

a Catalyst for Upgrading

5-Hydroxymethyl Furfural Into Liquid

Fuel Precursors.

Front. Microbiol. 10:1276.

doi: 10.3389/fmicb.2019.01276

\section{Synthesis of $\mathbf{P d} / \mathbf{R u}$ Bimetallic} Nanoparticles by Escherichia coli and Potential as a Catalyst for Upgrading 5-Hydroxymethyl Furfural Into Liquid Fuel Precursors

\author{
Jaime Gomez-Bolivar ${ }^{1 *}$, Iryna P. Mikheenko², Rafael L. Orozco², Surbhi Sharma², \\ Dipanjan Banerjee ${ }^{3,4}$, Marc Walker ${ }^{5}$, Rachel A. Hand ${ }^{6}$, Mohamed L. Merroun ${ }^{1}$ and \\ Lynne E. Macaskie ${ }^{2 *}$
}

${ }^{1}$ Department of Microbiology, Faculty of Sciences, University of Granada, Granada, Spain, ${ }^{2}$ School of Biosciences, University of Birmingham, Birmingham, United Kingdom, ${ }^{3}$ Dutch-Belgian Beamline, European Synchrotron Radiation Facility, Grenoble, France, ${ }^{4}$ Department of Chemistry, Katholieke Universiteit Leuven, Leuven, Belgium, ${ }^{5}$ Department of Physics, University of Warwick, Coventry, United Kingdom, ${ }^{6}$ Department of Chemistry, University of Warwick, Coventry,

United Kingdom

Escherichia coli cells support the nucleation and growth of ruthenium and ruthenium-palladium nanoparticles (Bio-Ru and Bio-Pd/Ru NPs). We report a method for the synthesis of these monometallic and bimetallic NPs and their application in the catalytic upgrading of 5-hydroxymethyl furfural (5-HMF) to 2,5 dimethylfuran (DMF). Examination using high resolution transmission electron microscopy with energy dispersive $X$-ray microanalysis (EDX) and high angle annular dark field (HAADF) showed $\mathrm{Ru} N P s$ located mainly at the cell surface using $\mathrm{Ru}($ (III) alone but small intracellular Ru-NPs (size $\sim 1-2 \mathrm{~nm}$ ) were visible only in cells that had been pre-"seeded" with $\operatorname{Pd}(0)$ (5 wt\%) and loaded with equimolar $\mathrm{Ru}$. $\mathrm{Pd}(0) \mathrm{NPs}$ were distributed between the cytoplasm and cell surface. Cells bearing 5\% Pd/5\% Ru showed some co-localization of Pd and Ru but chance associations were not ruled out. Cells loaded to $5 \mathrm{wt} \% \mathrm{Pd} / 20 \mathrm{wt} \% \mathrm{Ru}$ showed evidence of core-shell structures (Ru core, $\mathrm{Pd}$ shell). Examination of this cell surface material using $X$-ray photoelectron spectroscopy (XPS) showed $\mathrm{Pd}(\mathrm{O})$ and $\mathrm{Pd}(\mathrm{II})$ and $\mathrm{Ru}(\mathrm{IV})$ and $\mathrm{Ru}(\mathrm{III})$, with confirmation by analysis of bulk material using X-ray absorption near edge structure (XANES) and extended X-ray absorption fine structure (EXAFS) analyses. Both Bio-Ru NPs and Bio-Pd/Ru NPs were active in the conversion of 5-HMF into 2,5-DMF but commercial Ru on carbon catalyst outperformed 5 wt\% bio-Ru by fourfold. While 5 wt\% Pd/20 wt\% Ru achieved 20\% yield of DMF the performance of the $5 \mathrm{wt} \% \mathrm{Pd} / 5 \mathrm{wt} \%$ Ru bio-catalyst was higher and comparable to the commercial $5 \mathrm{wt} \% \mathrm{Ru} / \mathrm{C}$ catalyst in a test reaction using commercial 5-HMF (> 50\% selectivity). 5-HMF was prepared by thermochemical hydrolysis of starch and cellulose with solvent extraction of 5-HMF into methyltetrahydrofuran (MTHF). Here, with MTHF as the reaction solvent the commercial $\mathrm{Ru} / \mathrm{C}$ catalyst had little activity (100\% conversion, negligible selectivity to DMF) whereas the $5 \mathrm{wt} \% \mathrm{Pd} / 5 \mathrm{wt} \% \mathrm{Ru}$ 


\begin{abstract}
bio-bimetallic gave 100\% conversion and 14\% selectivity to DMF from material extracted from hydrolyzates. The results indicate a potential green method for realizing increased energy potential from biomass wastes as well as showing a bio-based pathway to manufacturing a scarcely described bimetallic material.
\end{abstract}

Keywords: ruthenium bionanoparticles, Pd/Ru core-shells, 5-hydroxymethyl furfural conversion, 2,5-dimethyl furan synthesis, cellulose conversion

\section{INTRODUCTION}

Many types of living cells have the ability to template and form metallic nanoparticles (NPs) by reduction of soluble metal species. This has formed the subject of numerous studies and reviews (e.g., De Corte et al., 2012; Castro et al., 2014; Kulkarni and Maddapur, 2014; Singh, 2015; Singh et al., 2016). The goal is to develop alternative, facile, routes to the synthesis of industrially relevant catalysts using biomaterial scaffolds for catalytically active nanoparticles while preventing NP agglomeration and consequent loss of activity. Recent focus has moved toward the biosynthesis of bimetallic nanoparticles since these can have unique properties due to synergy of the metallic components. For example in $\mathrm{Pd} / \mathrm{Au}$ the formation of $\mathrm{Pd}^{\delta+} / \mathrm{Au}^{\delta-}$ was suggested to underlie the superior catalytic activity of the bimetallic (Gao and Goodman, 2012). However, synthesis of bimetallic NPs by chemical routes is more difficult than for monometallic counterparts. Various preparation methods of bimetallic nanostructures have been reviewed (e.g., ZaleskaMedynska et al., 2016) and a variety of shapes, properties and catalytic activities has been obtained. However, biosynthetic routes are relatively unexplored, despite the potential for applying the tools of synthetic biology to obtain targeted NP manipulation (Torgeman, 2017).

An early example of bio-Pd/Au NPs was reported by Deplanche (2008) and this bio-catalyst, made on Escherichia coli and Cupriavidus necator, was applied in two respective catalyses: partial oxidation of benzyl alcohol to benzaldehyde (Deplanche et al., 2011) and reduction of p-nitrophenol (Hosseinkhani et al., 2012). The former, together with bio-Pd/Au made by Desulfovibrio desulfuricans (Tran et al., 2012) had a core-shell structure ( $\mathrm{Au}$ core/Pd shell). This structure is formed by initially depositing "seeds" of $\operatorname{Pd}(0)$ nanoparticles with enzymatic assistance involving hydrogenases (Mikheenko et al., 2008; Deplanche et al., 2010). The resulting $\operatorname{Pd}(0)$ reduces $\mathrm{Au}(\mathrm{III})$ galvanically and oxidized Pd species migrate outward from the core of neo- $\mathrm{Au}(0)$ followed by their chemical reduction under hydrogen to form a shell of $\mathrm{Pd}(0)$ (Deplanche et al., 2012). Bio-Pd/Au core shells form inside the bacterial cytoplasm (Supplementary Figure S1), which implies uptake and processing mechanisms for these heavy metals, that have no known biological function. Although the bacteria remain metabolically competent during $\operatorname{Pd}(0)$ "seeding," as shown by the use of flow cytometry (Omajali et al., 2018), the routes by which the $\operatorname{Pd}(0)$ "seeds" are localized and then develop from initial Pd-nuclei is still unknown, despite that these are key to the patterning of the subsequent bimetallic. Following formation of the Pd "seeds" cell viability is lost rapidly, although hydrogenase activity persists for several hours (Mikheenko et al., 2008). The use of dead cells [and retention of the NPs upon them (Bennett et al., 2013)] ensures acceptability of the nanomaterial while mitigating against NP release into the environment. The need to supply $\mathrm{Pd}(\mathrm{II})$ in acidic solution $\left(10 \mathrm{mM} \mathrm{HNO}_{3}\right.$ ), was shown by previous optimization studies; the function of the acid is to protonate the polyanionic cell surface to permit access of the $\mathrm{PdCl}_{3}{ }^{-}$ion that predominates in solution. Importantly, deposition of the second metal is an abiotic process, which enables metal recovery from highly acidic solutions following "seeding" with $\mathrm{Pd}(0)$ under physiologically compatible conditions (Murray et al., 2018).

Using a similar approach, the formation of bimetallic bio-Pd/Pt NPs was recently reported (Murray et al., 2018). These were active in the catalytic reduction of $\mathrm{Cr}(\mathrm{VI})$ (Murray et al., 2018) and in the selective hydrogenation of soybean oil (Murray et al., 2018) and 2-pentyne (Murray et al., 2017) as well as in the catalytic upgrading of heavy oils from Canadian oilsands (Omajali et al., 2017), and oils produced by thermochemical processing of wet biomass (Kunwar et al., 2017). However, the arrangement of the metallic components in the NPs (e.g., alloys or core-shell structures) was not reported.

With a developing global focus on sustainable energy and green chemistry $\mathrm{Pd} / \mathrm{Ru}$ bimetallics have been highlighted in these areas but study of $\mathrm{Pd} / \mathrm{Ru}$ is neglected in comparison with $\mathrm{Pd} / \mathrm{Au}$. Raja et al. (1999) showed that the hydrogenation of hex-1-ene to $n$-hexane was several orders of magnitude higher via use of $\mathrm{Pd}_{6} \mathrm{Ru}_{6}$ clusters than with $\mathrm{Pd}$ alone. Later, Qui et al. (2006) showed higher conversion and selectivity in hydrogenation of cinnamyl alcohol using Pd/Ru catalyst compared to that obtained by using single metals. Luo W. et al. (2015) reported catalytic hydrogenation of levulinic acid by a Pd/Ru bimetallic alloy; here, the metals were randomly dispersed and the high catalytic activity was attributed to dilution and isolation of Ru by Pd (Kyriakou et al., 2012). Boucher et al. (2013) had previously attributed highly selective hydrogenations to isolated Pd atoms. On the other hand, oxidation of formic acid (Liu et al., 2012) was reported, and also oxidation of ethanol, the latter using Pd-Ru bimetallic-NPs on carbon; this catalyst comprised a mix of Pd metal, Ru oxides and Pd oxides (Monyoncho et al., 2015). A Pd-overlayer enhanced the activity of Ru-nanotubes in hydrogen oxidation (St. John et al., 2015). Clearly, the activity for a certain reaction relates to the metal arrangement in the NPs but production of $\mathrm{Pd} / \mathrm{Ru}$ core-shell structures is neglected. Modulating fcc and hcp ruthenium on the surface of a Pd-Cu alloy produced a core-shell (Yao et al., 2016) but the catalytic activities of hcp-dominated $\mathrm{Ru}-\mathrm{Cu}$ NPs and fcc-dominated Ru showed opposing results in hydrogenations of 4-nitrochlorobenzene and styrene according to the predominant 
type of $\mathrm{Ru}$. This highlights the potential to moderate selectivity according to the bimetallic fine structure but also cautions that the outcome of a reaction may be difficult to achieve if the metal arrangement is not controlled. Biomanufacture of $\mathrm{Pd} / \mathrm{Ru}$ NPs is not yet reported in the literature. An initial study (Omajali, 2015) suggested this route for making bimetallic NPs for the catalytic conversion of 5-hydroxymethyl furfural (5-HMF) to 2,5 dimethyl furan (DMF) but no NP characterization was performed.

$5-\mathrm{HMF}$ is a derivative of glucose, fructose (van Putten et al., 2013) or cellulose under thermochemical degradation (RománLeshkov et al., 2007). The product, DMF (Lei et al., 2014; Nagpure et al., 2015), is a "platform" precursor of plastics and also of "drop in" fuels (Lei et al., 2014; Nagpure et al., 2015). "Drop-in" biofuels are defined as "liquid bio-hydrocarbons that are functionally equivalent to petroleum fuels and are fully compatible with existing petroleum infrastructure" (Karatzos et al., 2014). Working toward higher yields and selectivity toward DMF, studies have focused on "classical" mono and bimetallic catalysts including Pd and $\mathrm{Ru}$ (Hansen et al., 2012; Nishimura et al., 2014; Zu et al., 2014; Luo J. et al., 2015). Study of bacterially derived $\mathrm{Pd} / \mathrm{Ru} \mathrm{NPs}$ is a new development. Omajali et al. (2019) showed the potential of cells of the Gram-positive bacterium Bacillus benzeovorans to make bio$\mathrm{Pd} / \mathrm{Ru}$ bimetallic structures using the same approaches as described above for bio- $\mathrm{Pd} / \mathrm{Au}$ and bio-Pd/Pt. Most of the work on bio-NP catalysts has used Gram-negative bacteria. Deplanche et al. (2014) and Zhu (2014) noted that bio-Pd catalysts supported on typical Gram-positive cells were less active catalytically than those on Gram negative bacteria. Hence the primary aim of this work was to evaluate the potential for the use of the paradigm Gram negative E. coli to synthesize $\mathrm{NPs}$ of bio-Ru and bio- $\mathrm{Pd} / \mathrm{Ru}$ and evaluate their potential for the catalytic upgrading of 5-HMF to DMF. In order to move toward real-life application the upconversion of 5-HMF derived from thermochemical hydrolysis of starch and cellulose was also evaluated.

The use of E. coli is attractive as this ubiquitous organism is readily grown at scale and waste $E$. coli cells grown for another primary process (biohydrogen production) were successfully used in "second life" to make bio-Pd catalyst for hydrogenation (Zhu et al., 2016) and in fuel cells (Orozco et al., 2010), while the ability to fabricate the metallic catalyst from liquid wastes (Yong et al., 2010, 2015; Murray et al., 2017) has positive implications for both economy and sustainability.

\section{MATERIALS AND METHODS}

\section{Bacteria, Growth Conditions, and Chemicals Used}

Escherichia coli strain MC4100, grown as described by Deplanche et al. (2012), was harvested in midlogarithmic phase $\left(\mathrm{OD}_{600}\right.$ of $\left.0.7-1.0\right)$ by centrifugation $\left(9,000 \times g, 15 \mathrm{~min}, 4^{\circ} \mathrm{C}\right)$, washed three times $(20 \mathrm{mM}$ MOPS-NaOH buffer, $\mathrm{pH}$ 7.0) and routinely stored as a concentrated suspension overnight $\left(4^{\circ} \mathrm{C}\right)$. The cell dry weight was estimated from a previously determined OD/dry weight conversion.

Commercial metal salts $\left(\mathrm{Na}_{2} \mathrm{PdCl}_{4}\right.$ and $\left.\mathrm{RuCl}_{3}\right)$ were from Sigma-Aldrich, as were $5 \mathrm{wt} \% \mathrm{Pd}$ and $5 \mathrm{wt} \% \mathrm{Ru}$ on carbon catalysts and commercial 5-HMF ( $\geq 99 \%)$ and 2,5-DMF (99\%).

\section{Preparation of Monometallic and Bimetallic Bionanoparticles (Bio-NPs)}

For monometallic bio-Ru cell suspension was diluted into $2 \mathrm{mM}$ $\mathrm{Ru}$ (III): $\mathrm{RuCl}_{3} \cdot 2 \mathrm{H}_{2} \mathrm{O}$ solution ( $\mathrm{pH} 2$, in $10 \mathrm{mM} \mathrm{HNO}_{3}$ ) to the required biomass/metal ratio for the desired loading (5 $\mathrm{wt} \%)$ and left for $30 \mathrm{~min}\left(30^{\circ} \mathrm{C}\right)$ for metal uptake by the cells. $\mathrm{H}_{2}$ was bubbled through the suspension for $1 \mathrm{~h}$ and left for $96 \mathrm{~h}$ (sealed bottle; $180 \mathrm{rpm}$ agitation; $\left.30^{\circ} \mathrm{C}\right)$. Monometallic bio-Pd (5 wt\%) was made similarly, according to Deplanche et al. (2012).

Synthesis of bimetallic Pd/Ru used, sequentially, a $2 \mathrm{mM} \mathrm{Pd}$ (II) and then a $1 \mathrm{mM} \mathrm{Ru}$ (III) solution (in $10 \mathrm{mM} \mathrm{HNO}_{3}$ ) by the method of Deplanche et al. (2012) with modifications: $2 \mathrm{mM}$ Pd (II) solution was reduced to $\mathrm{Pd}(0)$ on the cells under $\mathrm{H}_{2}$ (30 min; complete removal (by assay) of residual soluble metal) to give $5 \mathrm{wt} \%$ bio- $\mathrm{Pd}(0)$. The bio- $\mathrm{Pd}(0)$ was washed twice (distilled water, DW), and added as a concentrated suspension into $1 \mathrm{mM} \mathrm{Ru}$ (III) solution (final concentration; volume was adjusted to give the required final metal loading on cells) to give a final loading of (nominally) $5 \mathrm{wt} \% \mathrm{Pd} / 5 \mathrm{wt} \% \mathrm{Ru}$ or $5 \mathrm{wt} \% \mathrm{Pd} / 20 \mathrm{wt} \% \mathrm{Ru}$. The bio-Pd/Ru mixture was left to stand then saturated with $\mathrm{H}_{2}$ (as above; $180 \mathrm{rpm}, 30^{\circ} \mathrm{C} ; 96 \mathrm{~h}$ ). The presumptive bio-NPs were washed three times (DW) and once with acetone $\left(9,000 \times g, 15 \mathrm{~min}, 4^{\circ} \mathrm{C}\right)$, air-dried and ground manually. The actual Ru loadings were determined by difference via assay of residual soluble $\mathrm{Ru}(\mathrm{III})$ by the stannous chloride method (Charlot, 1978); Pd was completely removed in the first step and was retained on the cells (as determined by assay of wash solutions).

\section{High Resolution Scanning-Transmission Electron Microscopy (STEM) With HAADF (High-Angle Annular Dark Field) Detector, Energy Dispersive X-Ray Analysis (EDX), and Determination of Lattice Spacing}

Where cell sections were to be examined, fresh preparations were fixed $[2.5 \%(\mathrm{w} / \mathrm{v})$ glutaraldehyde fixative in $0.1 \mathrm{M}$ cacodylate buffer, $\mathrm{pH} 7.2 ; 2 \mathrm{~h}$ at $4^{\circ} \mathrm{C}$ ], washed three times with the same buffer and stained (1\% aq. osmium tetraoxide). For TEM thin samples were prepared as described previously (Deplanche et al., 2012). Electron opaque deposits were examined by EDX with peaks sought corresponding to X-ray emission energies of $\mathrm{Ru}$ and Pd. STEM and EDX were done using a FEI image Cscorrector configuration Titan ${ }^{\mathrm{TM}}$ G2 60-300 STEM microscope equipped with HAADF detector, accelerating voltage of $300 \mathrm{kV}$. Lattice spacings were determined using "Image)" (Abramoff et al., 2004) through profiling of high resolution HAADFSTEM images. 


\section{X-Ray Photoelectron Spectroscopy (XPS) of Cell Surfaces}

Subsamples (a few $\mathrm{mg}$ ) were retained and air-dried. Surface chemical composition and oxidation state analyses were done by XPS via published methods (Omajali et al., 2017) using a Kratos Axis Ultra DLD spectrometer (Kratos Analytical). The samples were illuminated using an $\mathrm{Al} \mathrm{K} \alpha \mathrm{x}$-ray source and the photoelectrons were collected using a hemispherical electron analyzer. Survey spectra were recorded using a pass energy of $160 \mathrm{eV}$, with the pass energy reduced to $20 \mathrm{eV}$ for acquisition of the core level spectra (resolution approx. $0.4 \mathrm{eV}$ ). The samples were insulating, therefore a charge neutralizer was used to prevent surface charging with a low energy electron beam directed onto the sample during XPS data acquisition. Measurements were made at room temperature and at a take-off angle of $90^{\circ}$, to probe a depth of approx. 5-10 nm to examine bio-NPs bound to the outermost cell surfaces. Generated data were converted into VAMAS format and analyzed using the CasaXPS package (Fairley, 2013) employing Shirley backgrounds, mixed Gaussian-Lorentzian (Voigt) lineshapes and asymmetry parameters where appropriate. All binding energies were calibrated to the $\mathrm{C} 1 \mathrm{~s}$ peak originating from $\mathrm{C}-\mathrm{H}$ or $\mathrm{C}-\mathrm{C}$ groups at $284.8 \mathrm{eV}$.

\section{X-Ray Absorption Spectroscopy (XAS) Analysis}

This synchrotron radiation based technique was used to determine the local coordination of Pd and $\mathrm{Ru}$ in the biogenic $\mathrm{Pd} / \mathrm{Ru}$ NPs samples. Pd and Ru K-edge XAS spectra were acquired at the Dutch-Belgian Beamline (DUBBLE) beamline at the European Synchrotron Radiation Facility (ESRF), Grenoble (France), using a $\mathrm{Si}(111)$ monochromator operating in fixed-exit mode. Data were acquired using $\mathrm{Ar} / \mathrm{He}$ filled ionization chambers (transmission mode). The energies were calibrated by measuring the $\mathrm{Pd}$ and $\mathrm{Ru}$ K-edge transmission spectra of $\mathrm{Pd}$ and $\mathrm{Ru}$ foils and were calibrated to 24350 and $22117 \mathrm{eV}$, respectively. Samples ( $\mathrm{Ru}$ and $\mathrm{Pd} / \mathrm{Ru}$-loaded cells) were examined as dry samples (powder, a few $\mathrm{mg}$ ). Data were processed using the ATHENA code (Ravel and Newville, 2005) with subtraction of background via a preedge linear function. Atomic absorption was simulated with a square-spline function. The amplitude reduction factor was held constant at 1.0 for the FEFF8 calculation and extended X-ray absorption fine structure (EXAFS) fits, with the shift in threshold energy, $\Delta \mathrm{E} 0$, varied as a global parameter. The theoretical scattering phase and amplitude functions used in data analysis were calculated using FEFF8 (Ankudinov et al., 1998). For the Pd edge EXAFS spectra, data for phase-shifts and backscattering amplitudes were obtained from reference materials of PdO (Pd-O scattering) and $\mathrm{Pd}$ foil (Pd-Pd scatterings). For the $\mathrm{Ru}$ edge EXAFS spectra, data for phase-shifts and backscattering amplitudes were obtained from $\mathrm{RuO}_{2}$ ( $\mathrm{Ru}-\mathrm{O}$ scattering), $\mathrm{Ru}$ foil ( $\mathrm{Ru}-\mathrm{Ru}$ scatterings), and $\mathrm{RuCl}_{3}(\mathrm{Ru}-\mathrm{Cl}$ scattering) reference compounds.

\section{Preparation of 5-HMF via Thermochemical Hydrolysis of Starch and Cellulose}

Methods for thermal hydrolysis were as reported previously (Orozco et al., 2012). For starch/cellulose hydrolysis the batch reactor system comprised a bench top reactor $(100 \mathrm{ml}$; Parr series 4590; pressure 200 bar; temperature $350^{\circ} \mathrm{C}$ ) of Type 316 stainless steel equipped with a heat/agitation controller (Parr 4848). Temperature and pressure were measured from inside the reactor and maintained within 1 bar and $0.1 \mathrm{~K}$, respectively.

For hydrolysis the material (starch $(7.2 \mathrm{~g}$, from potato powder; Sigma-Aldrich) or cellulose (5.1 g, Sigma-Aldrich) was suspended in de-ionized water (final reactant volume of $60 \mathrm{ml}$ for starch; $120 \mathrm{~g} / \mathrm{l}$ and $70 \mathrm{ml}$ for cellulose; $72.9 \mathrm{~g} / \mathrm{l}$ ) or as otherwise stated) and charged into the reactor for hydrolysis (head space $\sim 120 \mathrm{ml}$ ). The reactor was sealed, purged with $\mathrm{N}_{2}$ three times, pressurized (30 bar), heated to the set-point temperature $\left(220^{\circ} \mathrm{C}\right.$ for starch, $260^{\circ} \mathrm{C}$ for cellulose; agitation $300 \mathrm{rpm}$ ), held for $15 \mathrm{~min}$ and cooled by submersion in cold water. The hydrolyzate was separated (after depressurization) from solid residue (vacuum filtration; filter paper Fisherbrand QL100) or by centrifugation (10,000 rpm; $10 \mathrm{~min})$. Hydrolyzates and samples were kept at $4^{\circ} \mathrm{C}$ prior to analysis. The reactions were repeated as required to produce sufficient pooled starch and cellulose-derived 5-HMF for the upconversion tests.

Hydrolyzates were analyzed using a GC (Shimadzu, 2010 equipped with an autosampler AOC-20S, a FID detector and ZB-Wax column $(30 \mathrm{~m} \times 0.25 \mathrm{~mm} \times 0.25 \mu \mathrm{m})$; injection volume $1 \mathrm{\mu l}$; inlet temperature $260^{\circ} \mathrm{C}$; injector temperature $300^{\circ} \mathrm{C}$; detector temperature; $300^{\circ} \mathrm{C}$, inlet pressure $100 \mathrm{KPa}$; split ratio of 100:1 with $\mathrm{H}_{2}$ carrier gas at a flow rate of $1 \mathrm{ml} / \mathrm{min}$ ). The heating gradient was $0 \mathrm{~min} \mathrm{GC}$ temp $100^{\circ} \mathrm{C} ; 10 \mathrm{~min}$ GC temp $200^{\circ} \mathrm{C} ; 22$ min GC temp $200^{\circ} \mathrm{C}$; and $25 \mathrm{~min}$ GC temp $250^{\circ} \mathrm{C}$. Reaction residues were not quantified nor analyzed.

\section{Solvent Extraction of 5-HMF Using 2-Methyltetrahydrofuran (2-MTHF)}

The method for 5-HMF extraction was based from the experimental determination of partition coefficients under batch and continuous conditions according to Blumenthal et al. (2016). The mass transfer of 5-HMF from the aqueous to the organic phase is faster at $60^{\circ} \mathrm{C}$ and concentrations of 5HMF in the range between $1-5 \mathrm{wt} \%$ in the aqueous feed had little effect on the partition coefficients. Therefore, the produced starch and cellulose hydrolyzates, respectively, were mixed in equal volumetric proportions with 2-MTHF (organic extraction solvent) in an Erlenmeyer flask at $200 \mathrm{rpm}$ and $60^{\circ} \mathrm{C}$ using a magnetic stirrer and a temperature-controlled water bath $(25 \mathrm{~min})$. After extraction aqueous and organic phases were separated using a separation funnel: the top organic phase was "supernatant" and the bottom aqueous phase was "hydrolyzate." Both phases were sampled and kept at $-20^{\circ} \mathrm{C}$ before analysis by GC. 
Solvent extraction efficiency was calculated using the following formula:

Extraction efficiency $(\%)=$

$$
\frac{\text { moles of } 5 \text {-HMF in supernatant }}{\text { moles of 5-HMF in hydrolyzate }} \times 100
$$

\section{Catalytic Conversion of 5-Hydroxymethyl Furfural to 2,5-Dimethyl Furan}

Starch and cellulose derived 5-HMF were obtained via hot compressed water treatment (Orozco, 2012; Orozco et al., 2012) followed by solvent extraction of 5-HMF using MTHF (as above). The catalytic transfer hydrogenation reactions used a $100 \mathrm{ml}$ Parr series 4590 bench top reactor of Type 316 stainless steel equipped with a heat/agitation controller (Parr 4848). Three sets of experiments were carried out: set 1 (commercial 5-HMF); set 2 (starch-derived 5-HMF); and set 3 (cellulose-derived 5-HMF). For set 1 the reactor was charged with $250 \mathrm{mg}$ of $5-\mathrm{HMF}$ in $25 \mathrm{ml}$ of MTHF ( $80 \mathrm{mM} 5$-HMF solution); for sets 2 and 3 volumes of 28 and $50 \mathrm{ml}$ of 5-HMF in MTHF were extracted from starch and cellulose hydrolyzates, respectively. In all sets a weight ratio of 2.5:1 of 5-HMF:catalyst was added to the reactor. The reactor was sealed, purged three times with $\mathrm{H}_{2}$ (50 bar), pressurized with $\mathrm{H}_{2}$ (50 bar), and heated $\left(260^{\circ} \mathrm{C} ; 2 \mathrm{~h} ; 500 \mathrm{rpm}\right)$. After the reaction (time as determined by prior tests), the reactor was quenched to $35-40^{\circ} \mathrm{C}$ in a water bath and the reaction mixture was filtered (Fisherbrand QL100 filter paper). Samples were stored at $-20^{\circ} \mathrm{C}$ before analysis using a GC-FID for quantification and a GCMS-QP2010s for compound identification. All GC-FID analysis was performed on a Shimadzu GC2014 GC equipped with a Shimadzu AOC-20i autosampler. The carrier gas was hydrogen, supplied by an external hydrogen generator (Parker). The GC was fitted with a Restek Stabilwax-DA column $(30 \mathrm{~m}$ length, $0.32 \mathrm{~mm} \mathrm{ID}$, and $0.25 \mu \mathrm{m}$ film thickness). The injection volume was $1 \mu \mathrm{l}$ with a 39 split ratio. The inlet temperature was $250^{\circ} \mathrm{C}$. The detector was a flame ionization detector (FID) with a flame temperature of $300^{\circ} \mathrm{C}$, and a sampling rate of $40 \mathrm{~ms}$. The heating profile was $60^{\circ} \mathrm{C}$ for $2 \mathrm{~min}$ then heated to $200^{\circ} \mathrm{C}$ at $5^{\circ} \mathrm{C} / \mathrm{min}$ min followed by further heating to $240^{\circ} \mathrm{C}$ at $15^{\circ} \mathrm{C} / \mathrm{min}$ where it remained for a further $3 \mathrm{~min}$. Analysis was carried out using Shimadzu GCsolutions software. Calibration curves were third order between 80 and $0.4 \mathrm{mM}$.

All GC-MS analysis was performed on a Shimadzu GCMS-QP2010s equipped with a Shimadzu AOC-20i autosampler. The carrier gas was helium. The GC was fitted with a Restek Rxi-1ms column (15 m length, $0.25 \mathrm{~mm}$ ID and $0.25 \mu \mathrm{m}$ film thickness). The injection volume was $1 \mu \mathrm{l}$ with a -1 split ratio. The inlet temperature was $250^{\circ} \mathrm{C}$. The detector was a single quadrupole mass spectrometer in electron ionization mode. The detector and interface temperatures were $250^{\circ} \mathrm{C}$. The detector acquisition mode was scanning between $40-400 \mathrm{~m} / \mathrm{z}$, with a scan every $300 \mathrm{~ms}$. The solvent cut time was $1 \mathrm{~min}$. The heating profile was $60^{\circ} \mathrm{C}$ for $2 \mathrm{~min}$ then heated to $200^{\circ} \mathrm{C}$ at $5^{\circ} \mathrm{C} / \mathrm{min}$ followed by further heating to $240^{\circ} \mathrm{C}$ at $15^{\circ} \mathrm{C} / \mathrm{min}$ where it remained for a further $3 \mathrm{~min}$. Analysis was carried out using
Shimadzu GCMS Real-Time Analysis and Shimadzu GCMS Post Run Analysis software.

Conversion of 5-HMF and yields of DMF were calculated as follows:

$$
\begin{aligned}
& \text { 5-HMF conversion in }(\%)= \\
& \left(1-\frac{\text { moles of } 5 \text {-HMF in products }}{\text { starting moles of 5-HMF }}\right) \times 100 \\
& \text { 2, 5-DMF yield }(\%)= \\
& \left(\frac{\text { moles of } 2,5 \text {-DMF in products }}{\text { starting moles of 5-HMF }}\right) \times 100
\end{aligned}
$$

\section{2, 5-DMF selectivity $(\%)=$}

$$
\begin{gathered}
\left(\frac{\text { moles of } 2,5-\mathrm{DMF} \text { in products })}{\text { starting moles of } 5 \text {-HMF }- \text { final moles of } 5 \text {-HMF }}\right) \\
\times 100
\end{gathered}
$$

Other products were not identified or quantified.

\section{RESULTS AND DISCUSSION}

\section{Uptake of $\mathrm{Pd}(\mathrm{II})$ and $\mathrm{Ru}(\mathrm{III})$ by the Cells and Formation of Bio-Pd and Bio-Ru NPs}

Initial studies using $\mathrm{Pd}(\mathrm{II})$ showed its rapid, complete removal from solution by E. coli (Deplanche et al., 2010) and conversion into $\mathrm{Pd}(0)-\mathrm{NPs}$, both at the cell surface and intracellularly, within 30 min (Supplementary Figure S2). In contrast, with $\mathrm{Ru}(\mathrm{III})$, only $\sim 50 \%$ of the $\mathrm{Ru}(\mathrm{III})$ was removed, even after $96 \mathrm{~h}$ (Table 1); hence, the nominally $5 \mathrm{wt} \% \mathrm{Ru}$ was actually $2.6 \%$ of the cell dry weight. Thermogravimetric analysis of $D$. desulfuricans biomass (Omajali et al., 2017) showed that typically more than $50 \%$ of the

\begin{tabular}{|c|c|c|c|c|c|c|}
\hline & & \multicolumn{2}{|c|}{ Nominal wt $\%$} & \multicolumn{2}{|c|}{ Actual wt $\%$} & \multirow{2}{*}{$\begin{array}{c}\text { Metal loading } \\
\text { per catalyst } \\
\text { (actual, wt } \% \text { ) }\end{array}$} \\
\hline & & Pd & $\mathbf{R u}$ & Pd & Ru & \\
\hline I & $5 \%$ bio-Ru & 0 & $5.0 \%$ & 0 & $* 2.6 \%$ & $2.6 \%$ \\
\hline$\|$ & $5 \% / 5 \%$ bio-Pd/Ru & $5.0 \%$ & $5.0 \%$ & $5.0 \%$ & $* 4.7 \%$ & $9.7 \%$ \\
\hline III & $5 \% / 20 \%$ bio-Pd/Ru & $5.0 \%$ & $20 \%$ & $5.0 \%$ & $* 17.5 \%$ & $22.5 \%$ \\
\hline
\end{tabular}
material remains at above $600^{\circ} \mathrm{C}$, comprising residual carbon and mineral components. Hence, for the purpose of this comparison, the $2.6 \mathrm{wt} \%$ bio- $\mathrm{Ru}$ (on air dried cells) and commercial $5 \mathrm{wt} \%$ $\mathrm{Ru} / \mathrm{C}$ catalysts are assumed to be broadly comparable in terms of metal/carbon but the dosing of catalyst metal into the catalytic

TABLE 1 | Materials examined in this study prepared on cells of Escherichia coli.

* The actual metal loading was determined by difference from the Ru(III) provided and that found in the spent solution by assay of the spent solution by assay (see text). $R$ u(III) sample $(0.2 \mathrm{ml}$, aq.) was added to $0.8 \mathrm{ml}$ of stannous chloride $(29.9 \mathrm{~g}$ $\mathrm{SnCl}_{2}$ in $500 \mathrm{ml}$ conc. $\mathrm{HCl}$ ) and incubated at $30^{\circ} \mathrm{C}$ (30 min). Ru(III) was estimated at $A_{400}$ with reference to a $R u(I I I)$-calibration similarly determined and was linear in the region of interest. Note that atomic weights of Pd and Ru are 106.4 and 101.1, respectively; hence sample II was near-equimolar. 
tests (see later) would be $\sim$ half in terms of metallic component of the biomaterial on a comparable weight basis. However, the two catalysts are probably not comparable in terms of available catalyst surface; attempts to establish the surface area of bio-Pd by standard sorption methods were unsuccessful (Bennett and Macaskie, unpublished).

Examination of $5 \mathrm{wt} \%$ bio-Pd (the "seeds" to promote Ru deposition) showed that Pd-free cells had no nanoparticles. The deposition of $\operatorname{Pd}(0)$ on/in the challenged cells was very similar to that reported for bio-Pd made on $D$. desulfuricans (Omajali et al., 2015 and Supplementary Figure S2). A full characterization of the bio-Pd on E. coli will be was described by Gomez-Bolivar et al. (2019).

In contrast, cells challenged with $\mathrm{Ru}(\mathrm{III})$ alone showed localization of electron opaque NPs detectable only at the cell surface (Figures 1A-E) and also in material extruded from the cell surface both at $2.6 \mathrm{wt} \% \mathrm{Ru}$ (not shown) and in cells loaded with $\mathrm{Ru}$ to (nominally) $20 \mathrm{wt} \% \mathrm{Ru}$ (the actual loading here was not determined) (Supplementary Figure S3). Analysis of the cell surface (Figure 1C) and exuded material (Supplementary Figure S3) using EDX confirmed the presence of Ru, while HR TEM (Figures 1F,G) showed discrete NPs of size $\sim 2-3 \mathrm{~nm}$, with lattice spacings of $0.210 \mathrm{~nm}$, which may be assigned to the $\{101\}$ face of Ru metal (0.205 nm: Ghosh and Chen, 2008). However, other studies (Kim et al., 2001) concluded that $\mathrm{RuO}_{2}$ forms as a surface layer by epitaxial growth on the surface of $\mathrm{Ru}$ in a lattice-matched manner; indeed, Leng et al. (2014) attributed a lattice fringe of $0.205 \AA$ to the $\{210\}$ face of $\mathrm{RuO}_{2}$ synthesized on graphene. In situ synchrotron $\mathrm{X}$-ray diffraction showed the direct transition of amorphous $\mathrm{Ru}(\mathrm{OH})_{3} \cdot \mathrm{H}_{2} \mathrm{O}$ to crystalline $\mathrm{RuO}_{2} \mathrm{NPs}$, i.e., the evolution of $\mathrm{Ru}(\mathrm{IV})$ from $\mathrm{Ru}(\mathrm{III})$ (Park et al., 2015). The hydrolysis behavior of the $\mathrm{Ru}^{3+}$ ion in the current study would be suppressed at the acidic $\mathrm{pH}$ used for metal uptake (as described by Deplanche et al., 2012) but following metal exposure (under $\mathrm{H}_{2}$ ) the cells were washed in water and left in air prior to analysis and hence oxidation of any residual $\mathrm{Ru}(\mathrm{III})$ in air cannot be precluded. As some of the X-ray emission energies of $\mathrm{Ru}$ and $\mathrm{Cl}$ overlap [respectively, $\mathrm{keV} 2.56(\mathrm{~L} \alpha) 2.68(\mathrm{~L} \beta)$ and $2.62(\mathrm{~K} \alpha \mathrm{Y}) ; 2.81(\mathrm{~K} \beta) \mathrm{keV}]$ elemental mapping cannot preclude deposition of $\mathrm{RuCl}_{3}$ [in contrast the emission lines of $\mathrm{Pd}$ are (keV) 2.84 (L $\alpha 1), 2.99$ (L $\beta 1), 3.17$ (L $\beta 2)$, and $3.33(\mathrm{~L} \gamma)$ ]. Hence, XPS analysis of metal and chloride speciation at the cell surface was performed (see later).

$\mathrm{Ru}$ was not apparently taken up into the cytoplasm (Figure $\mathbf{1}$ and Supplementary Figure S3) and the extruded material is suggested to be of cell surface origin, since outer membrane vesicles containing $\mathrm{Ru}$ were visible (see later). The $\mathrm{Ru}$-deposition extended through the thickness of the cell wall layer (Figure 1E). There is little information on the interactions of $\mathrm{Ru}(\mathrm{III})$ with living cells but Ru-complexes are very common, e.g., rutheniumamine complexes are reported to have antitumor activity (e.g., Lima et al., 2014) while a recent report (Luo et al., 2018) describes the formation of $\mathrm{Ru}(\mathrm{III})$ complexes with collagen, a structural protein. In bacteria it seems likely that incoming $\mathrm{Ru}(\mathrm{III})$ is intercepted by amine groups of the periplasmic peptidoglycan, while outer membrane proteins would also form binding sites for $\mathrm{Ru}(\mathrm{III})$; we surmise that the incoming $\mathrm{Ru}(\mathrm{III})$ is intercepted and held by ligands in the cell surface layers.

\section{Deposition of Ru and Pd/Ru by Cells of E. coli}

In contrast to the above, when loading the cells with $5 \mathrm{wt} \%$ $\mathrm{Pd} / 5 \mathrm{wt} \% \mathrm{Ru}$ or $5 \mathrm{wt} \% \mathrm{Pd} / 20 \mathrm{wt} \% \mathrm{Ru}$ the $\mathrm{Ru}(\mathrm{III})$ was removed from the solution by 94 and $88 \%$, respectively (Table 1). Clearly "seeding" with $5 \mathrm{wt} \% \mathrm{Pd}(0)$ promotes deposition of $\mathrm{Ru}$ as compared to challenge with $\mathrm{Ru}(\mathrm{III})$ alone. The nominal and actual loadings of $\mathrm{Ru}$ on the cells are shown in Table 1; for convenience the bimetallic samples will be described as "low-Ru" (5 wt $\% \mathrm{Pd} / 5 \mathrm{wt} \% \mathrm{Ru}$ ) and "high Ru" (5 wt $\% \mathrm{Pd} / 20 \mathrm{wt} \% \mathrm{Ru}$ ), respectively, a key difference being the greater proportion of Pd atoms in the samples with less Ru.

\section{Examination of Low-Ru Bimetallic by HRTEM and HAADF and Elemental Mapping}

Challenge of the cells with $\mathrm{Pd}(\mathrm{II})$ and $\mathrm{Ru}(\mathrm{III})$ individually suggested that, while the former entered the cells and formed intracellular deposits, $\mathrm{Ru}$ deposition was confined to the surface layers (above) and hence it was implied that only surface-located $\operatorname{Pd}(0)$ would be able to "seed" the formation of structured bimetallics. However, intracellular NPs were visible (Figures 2A,B); these, and also the surface-located NPs, contained both Pd and Ru (Figures 2C,D), with an enrichment of $\mathrm{Ru}$ in the latter region (Figure 2C). Elemental mapping (Figures 2E-H) confirmed the uniform distribution of Pd (Figure 2G), surface-enrichment of $\mathrm{Ru}$, the presence of small intracellular Ru-NPs and putative membrane vesicles containing Ru-NPs (Figure 2H and Supplementary Figure S4). Intracellularly, Pd-NPs predominated (Figure 2F). While some areas of the cell contained Pd-NPs only, the Ru-NPs were located mainly alongside Pd-NPs (Supplementary Figure S4) although an association between them was not proved.

To prove an association between $\mathrm{Pd}$ and $\mathrm{Ru}$ a cell surface NP transect (arrowed in Figure 2I) was analyzed (Figure 2J), showing an asymmetric hybrid structure with $\mathrm{Pd} / \mathrm{Ru}$ at one side and Pd-enriched at the other, corresponding to a sparse region of $\mathrm{Ru}$. The predominance of Pd in the NPs was confirmed by the lattice fringes $(0.24 \mathrm{~nm}$ : Figures $2 \mathrm{~K}, \mathrm{~L})$ assigned to $\operatorname{Pd}\{111\}$ facets (Omajali et al., 2015) in both the cell surface and intracellular NPs. The size of the NPs was $\sim 3 \mathrm{~nm}$ but a NP size distribution analysis was not attempted due to the difficulty of setting the NP boundary due to the indistinct nature of the NPs. Some size heterogeneity is apparent (Supplementary Figure S4) but it is not certain if the larger NPs are simply agglomerations of smaller ones. The mean NP size (for bio-Pd) was reported as $1.4 \mathrm{~nm}$ in $D$. desulfuricans (Omajali et al., 2015), while that for E. coli was similar, at $1.3 \mathrm{~nm}$ (Gomez-Bolivar et al., 2019) and will be detailed in a subsequent publication.

\section{Examination of High-Ru Bimetallic by HRTEM and HAADF and Elemental Mapping}

Figure 3 shows the NPs produced at the higher loading of $\mathrm{Ru}$. In contrast to the low-Ru samples (above) no intracellular 

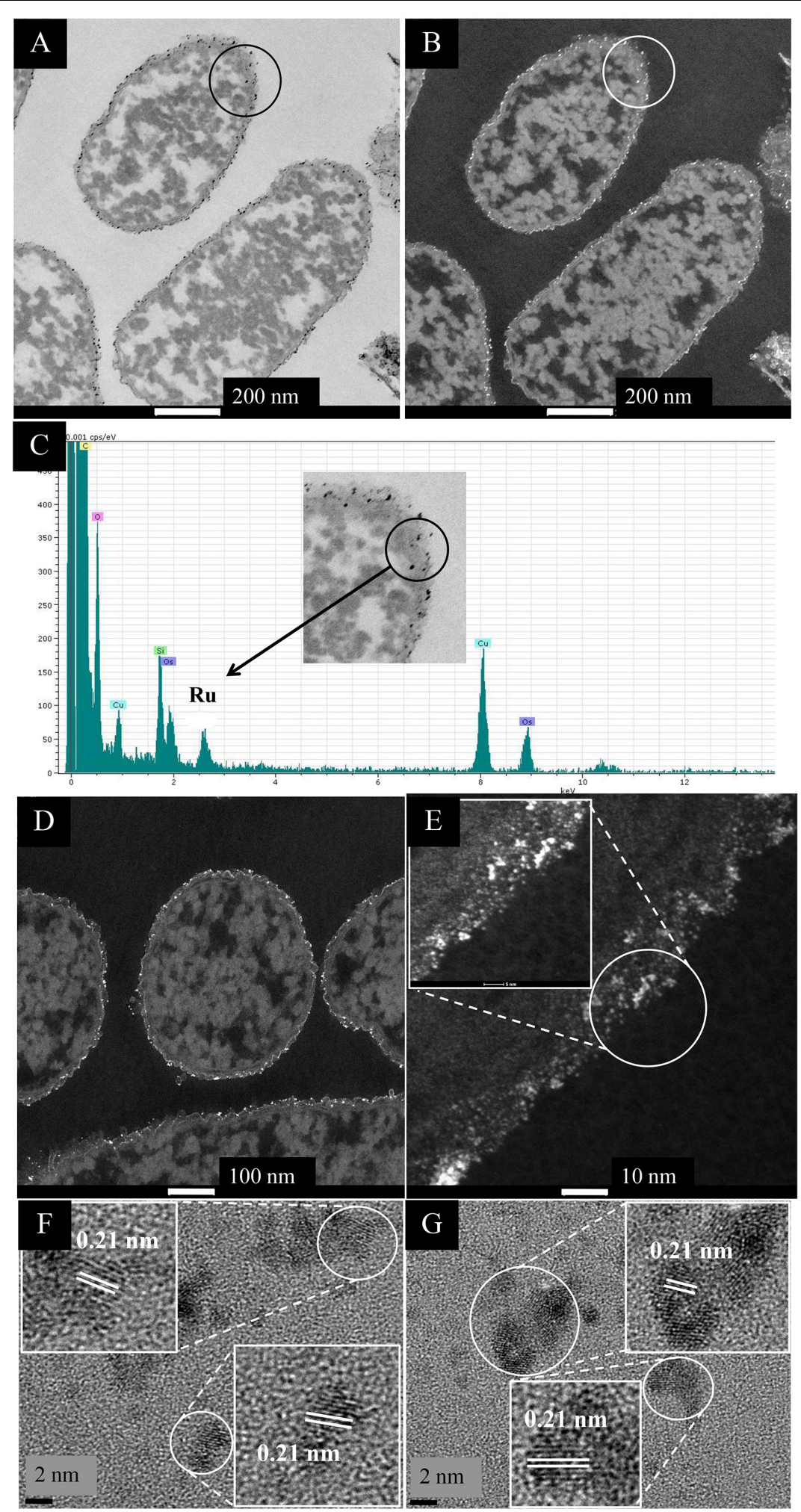

FIGURE 1 | EM study of E. coli MC4100 cells loaded to $2.6 \mathrm{wt} \%$ of Ru. (A,B) STEM/HAADF images of cell sections. For comparison cells with no added metal are shown in Supplementary Figure S2. Magnification of the circled section (inset) shows the presence of nanoparticles located in the membrane (C, inset.) EDX analysis confirmed the presence of Ru in the cell surface NPs (C). Cu is from the EM grid and Os from the stain. Bars are $100 \mathrm{~nm}$ (A,B). HAADF image is shown enlarged (D,E) revealing heterogeneity of Ru-NP sizes (E) and NP localization only in the periplasm (width of periplasm < $35 \mathrm{~nm}$ ). HR-TEM analysis of the circled area in panel $\mathbf{( E )}$ revealed consistent lattice spacing of $0.21 \mathrm{~nm}(\mathbf{F}, \mathbf{G})$ which can be attributed to either Ru metal or $\mathrm{RuO}_{2}$ (see text). 

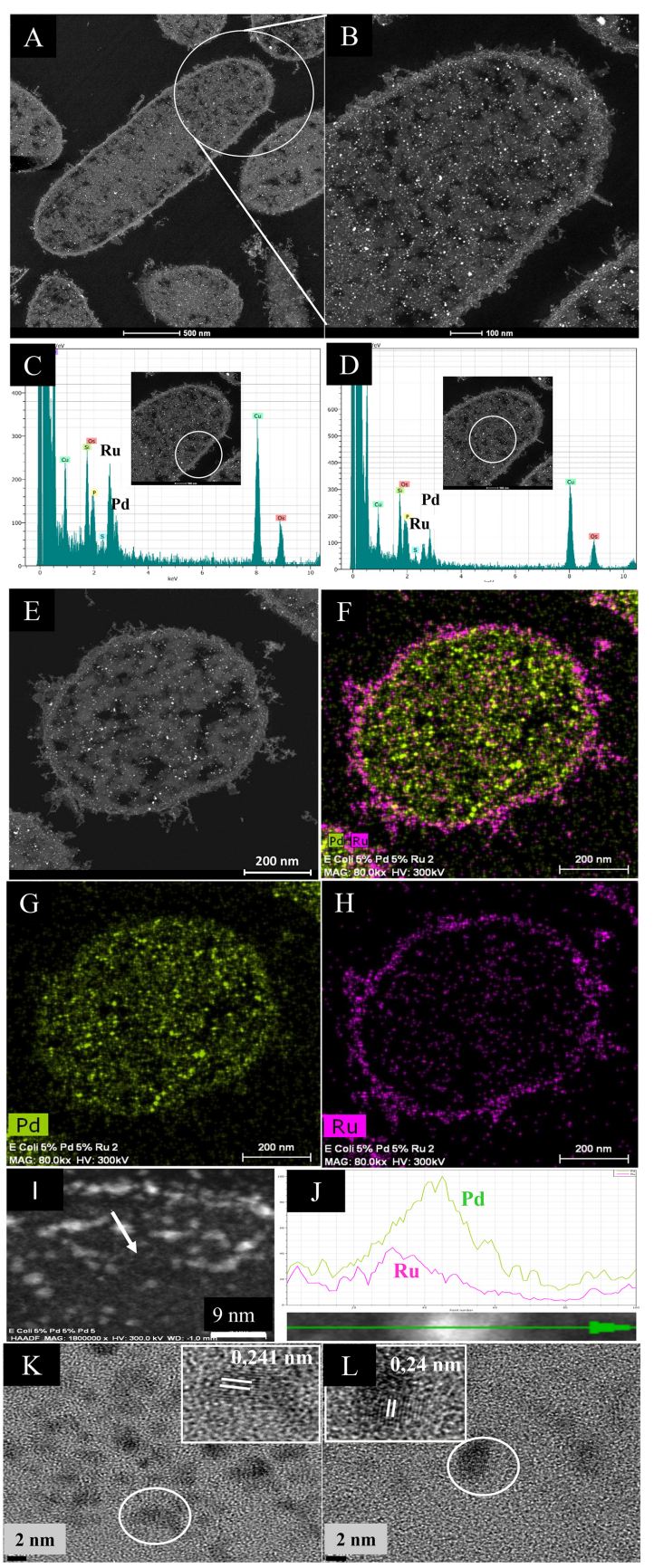

FIGURE 2 | HAADF/STEM micrographs of cell sections (A) and magnified view. Bars are $500 \mathrm{~nm}$ (B) of 5 wt\% Pd/5 wt\% Ru NPs. Bars are $100 \mathrm{~nm}$. EDX is shown of the cell surface (C) and intracellular (D) regions. A single cell $(\mathbf{E})$ is shown mapped for areas of $\mathrm{Pd}(\mathbf{G})$ and $\mathrm{Ru}(\mathbf{H})$ localization and co-mapped to show distribution of the two elements (F). Bars are $200 \mathrm{~nm}$. An enlarged image of panel $(\mathbf{F})$ is shown in Supplementary Figure $\mathbf{S} 4$ to show overall lack of co-mapping of the two elements on visual inspection but also that intracellular Ru is very evident. An example NP in the cell surface region (I, arrowed; scale bar is $9 \mathrm{~nm}$ ) was analyzed by transect (J) to show association between Pd (green) and Ru (magenta), especially evident on one side of the $\mathrm{NP}$ as a skewed distribution. The green arrow (bottom) shows distance across the transect (as a percentage 0-100\%) and the $Y$-axis is counts (arbitrary). $(\mathbf{K}, \mathbf{L})$ HRTEM images of single NPs from membrane-bound $(\mathbf{K})$ and cytoplasmic (L) NPs showing lattice fringes. Scale bar is $7 \mathrm{~nm}$.
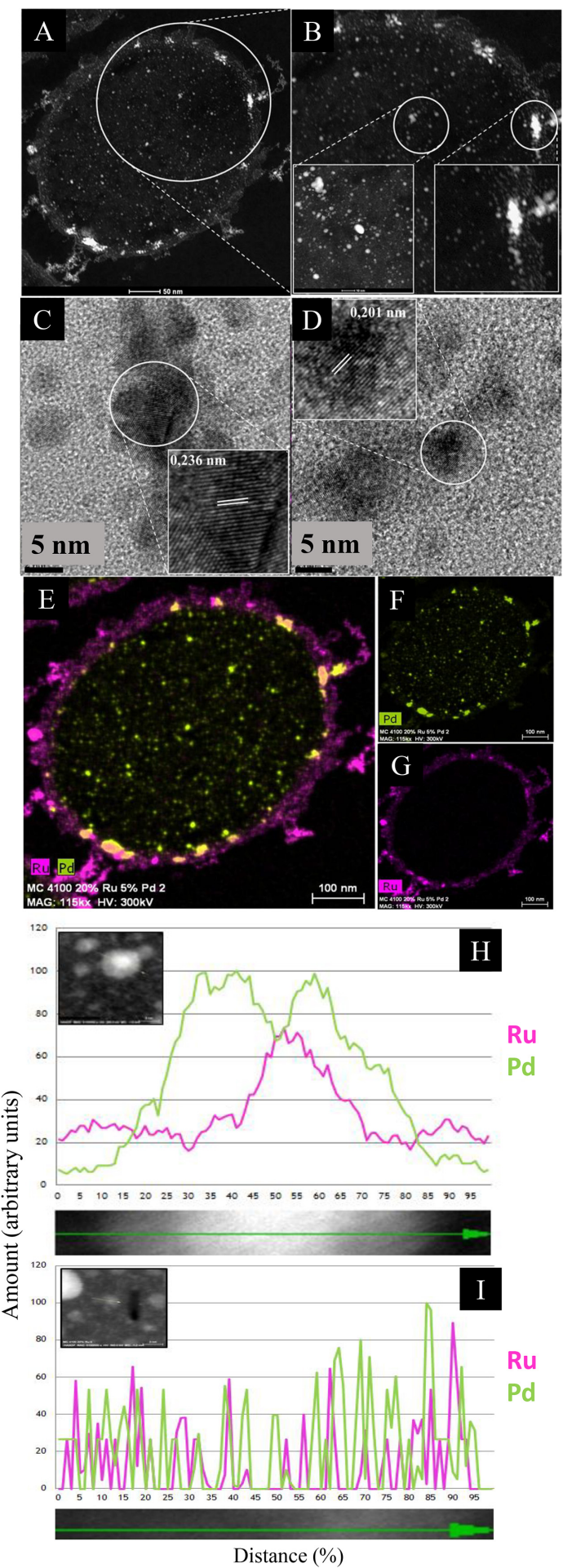

FIGURE 3 | HAADF/STEM micrographs of cell sections showing Pd/Ru NPs (5 wt\% Pd/20 wt\% Ru). (A) A higher magnification panel (B) shows NPs located in the cell surface layers (B, inset right) and in the bulk region (B, inset left). Lattice spacing of example NPs in cell wall layers and intracellularly are shown in, respectively (C,D). Elemental maps (by EDX) of cells show co-localization of $\mathrm{Pd}$ and $\mathrm{Ru}(\mathbf{E})$ and individually $\mathrm{Pd}(\mathbf{F})$ and $\mathrm{Ru}(\mathbf{G})$. Elemental maps (by EDX) of a single nanoparticle showing a core/shell structure $\mathbf{( H )}$ and random distribution (I) of $\mathrm{Pd}$ and $\mathrm{Ru}$. 
$\mathrm{Ru}$ NPs were apparent by electron microscopy (Figure 3G and Supplementary Figure S5) although some $\mathrm{Ru}$ was detected intracellularly by EDX (Supplementary Figure S6). Small and larger intracellular NPs were visible; the latter contained more Pd (Supplementary Figure S6). The reason for the apparently low cellular uptake of $\mathrm{Ru}$ and lack of Ru-NPs was not investigated but the higher dose of $\mathrm{Ru}$ was possibly lethal to the cells. The observation of intracellular Ru (Supplementary Figure S6) but not NPs (Figure 3E) also raises the question as to the actual role of $\mathrm{Pd}(0)$ seeds in the reduction of $\mathrm{Ru}(\mathrm{III})$ (assumed on the basis of earlier work using bio-Pd/Au: Deplanche et al., 2012) as a similar result to the low-Ru preparation (above) would be expected.

For catalysis the surface bound material would be more relevant and this was examined further. Lattice fringes $(0.236 \mathrm{~nm}$; Figure 3C) would correspond to $\operatorname{Pd}(0)\{111\}$. Other images (not shown) confirmed lattice fringes of $0.240 \mathrm{~nm}$, attributed to $\mathrm{Pd}\{111\}$ facets (Omajali et al., 2015) or possibly to the $\{110\}$ plane of $\mathrm{RuO}_{2}(0.231 \mathrm{~nm}$ : Soin et al., 2012), while the $0.201 \mathrm{~nm}$ lattice fringe (Figure 3D) could be $\mathrm{Ru}(0)\{101\} / \mathrm{RuO}_{2}$ $\{210\}$ (see later discussion).

In contrast to the low-Ru sample, regions of elemental overlap were clearly visible in the high-Ru sample (Figure 3E). An enlarged image (Supplementary Figure S5) shows numerous apparent core-shell structures as well as several "twinned" structures of the two metals alongside each other. In addition, a triplet structure ("dumbbell") is apparent that comprises a pivotal bimetallic region abutting onto separate nanostructures of both Pd and Ru (Supplementary Figure S5). These features contrast with the low-Ru preparation that shows no evident hybrid structures (Supplementary Figure S4).

The electron microscopy data would indicate that, with excess $\mathrm{Ru}$, the material comprises mostly a random deposition of $\mathrm{Pd}$ and $\mathrm{Ru} / \mathrm{RuO}_{2} \mathrm{NPs}$ but with some core-shell structures apparent visually. Examination of an area with a small undefined NP shows a largely random distribution of $\mathrm{Pd}$ and $\mathrm{Ru}$ with metal levels barely detectable above the background at the edge of the NP transect (Figure 3I). In contrast the patterning of a well-defined NP confirms a core-shell structure (Ru core/Pd shell) as described previously for Pd/Au (Au core/Pd shell: Deplanche et al., 2012). The previous studies on $\mathrm{Pd} / \mathrm{Au} \mathrm{NPs}$ also used Z-imaging, where the image intensity reflects the $\mathrm{Z}$ dependence on atomic number (Nellist and Pennycook, 2000); this can be used to localize atoms in NPs where elements of higher atomic number appear brighter. In bio-Pd/Au core-shells the Au-core was evident (Tran et al., 2012; Z Pd =46; Z Au =79) and, similarly, the Pt in Pd/Pt alloy (Z $\mathrm{Pt}=78$ : Esparza et al., 2017). However, since $\mathrm{Z}$ for $\mathrm{Ru}=44$ (i.e., very close to $\mathrm{Pd}$ ) the difference in contrast between the metals would be too small to detect. However, Figure $3 \mathbf{H}$ provides evidence for the occurrence of a similar structure in bio- $\mathrm{Pd} / \mathrm{Ru}$; the mechanism was assigned previously to re-oxidation of the $\operatorname{Pd}(0)$ "seeds" via galvanic reduction of the incoming $\mathrm{Au}(\mathrm{III})$ and migration of nascent $\mathrm{Pd}(\mathrm{II})$ around the NP, to be re-reduced under $\mathrm{H}_{2}$ to form the shell around the $\mathrm{Au}(0)$ core (Deplanche et al., 2012). In contrast to bio- $\mathrm{Pd} / \mathrm{Au}$, the $\mathrm{Pd} / \mathrm{Ru}$ core-shell structures occurred only occasionally and the occurrence (and persistence) of $\mathrm{Ru}(0)$ in the material is not proved (see above and later). Indeed, formation of $\mathrm{Ru}(\mathrm{IV})$ as $\mathrm{RuO}_{2}$ is suggested (i.e., oxidation of $\mathrm{Ru}(\mathrm{III})$ see later) which requires an electron sink. Petkov et al. (2017) attribute electronic interactions at surface metal interfaces $\left(\mathrm{Au}^{\delta+} ; \mathrm{Pd}^{\delta-}\right)$ as being responsible for high catalytic activity. It would seem possible that, in this case under $\mathrm{H}_{2}$ a core-shell may form, followed by (in air) oxidation of the $\mathrm{Ru}(0)$ component. It is known that a negatively charged $\mathrm{Pd}(0)$ can be formed by accepting electrons (i.e., behaving as a capacitor). Indeed, the capacitance (ability to store charge) of bio-Pd on E. coli was measured at 0.5-0.6 microamps in an electrochemical test system (at $20 \mathrm{wt} \% \mathrm{Pd}$ : Courtney et al., 2016).

However, $\mathrm{RuO}_{2}$ can evolve in air from $\mathrm{Ru}(\mathrm{III})$ (see above) without addition of a specific oxidant. No precaution was taken to exclude air following harvest of the NPs. It would seem that while $\mathrm{Ru}(\mathrm{III})$ may be reduced to $\mathrm{Ru}(0)$ into an occasional bimetallic core-shell (as for $\mathrm{Pd} / \mathrm{Au}$ ) it can also become oxidized to $\mathrm{Ru}(\mathrm{IV})$ and form $\mathrm{RuO}_{2}$ in air. While the core-shell may be stabilized by its Pd-overlay, the side by side NPs would leave Ru with an available surface for evolution into $\mathrm{RuO}_{2}$ while having $\mathrm{Pd}(0)$ nearby as a possible electron acceptor, a possible benefit of co-localization (Supplementary Figures S4, S5) without actual integration of the two metals.

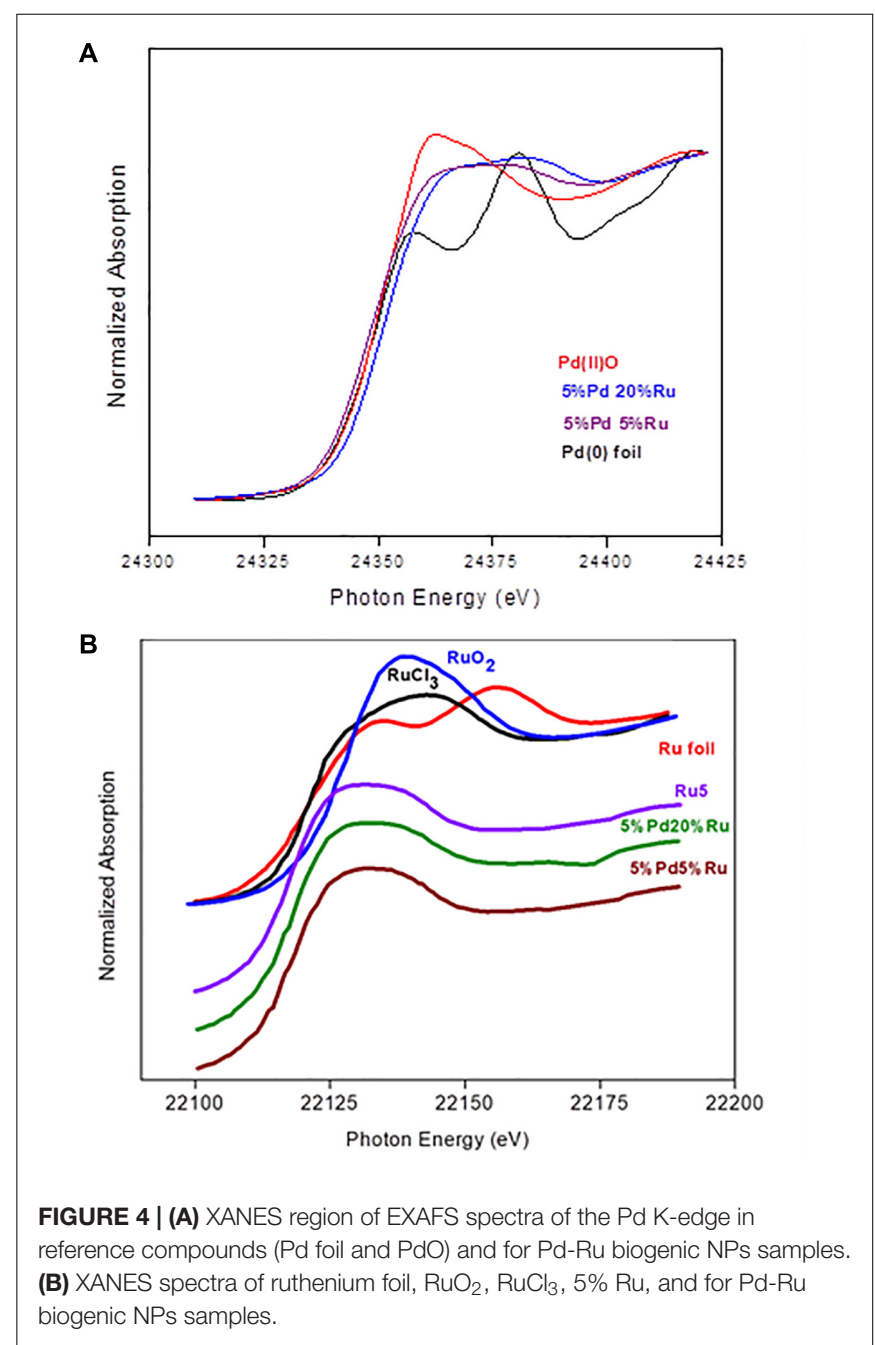




\section{Analysis of Bulk Material Using EXAFS: XANES Analysis}

$\mathrm{X}$-ray absorption near edge structure (XANES) is an elementspecific and local bonding-sensitive spectroscopic technique applied in this study to determine the oxidation state of $\mathrm{Ru}$ and $\mathrm{Pd}$ in the experimental samples. The analysis is based on relating small shifts (a few $\mathrm{eV}$ ) in XANES absorption edge energies with the average oxidation state of the central element. Spectra of Pd-foil and Ru-foil are shown in Supplementary Figure S7.

Figure 4A shows the XANES spectra of $\mathrm{Pd}$ reference compounds; palladium foil (metallic $\mathrm{Pd}$ ) and $\mathrm{PdO}[\mathrm{Pd}(\mathrm{II})]$, and biogenic $\mathrm{Pd} / \mathrm{Ru}$ NPs (low-Ru and high-Ru). The results obtained indicate that $\mathrm{Pd}$ is present as a mixture of $\mathrm{Pd}(0)$ and $\mathrm{Pd}(\mathrm{II})$ in the two $\mathrm{Pd} / \mathrm{Ru}$ samples. Linear combination fitting mode of ATHENA code was used to determine the relative amounts of $\mathrm{Pd}(0)$ and $\mathrm{Pd}(\mathrm{II})$ present in the bio-derived samples, revealing a mixture of $60 \%$ metallic palladium and $40 \% \mathrm{Pd}$ (II) for both bulk biogenic $\mathrm{Pd} / \mathrm{Ru}$ nanoparticles samples.

In the case of the Ru edge (Figure 4B), the XANES spectra of both biogenic NPs samples are different from that of $\mathrm{Ru}$ foil. In these samples, $\mathrm{Ru}$ is present as a mixture of $\mathrm{Ru}(\mathrm{III})$ and $\mathrm{Ru}(\mathrm{IV})$. However, linear combination fitting mode of ATHENA code showed the presence of low amounts of $\mathrm{Ru}(0)$ ranging between 6 and $10 \%$.

\section{EXAFS: Pd K-Edge}

The Pd K-edge EXAFS spectra of a palladium foil, and of low-Ru and high-Ru samples, along with their corresponding Fourier transforms (FT), are shown in Figure 5A. The fit parameters of the calculated spectra are summarized in Table 2.

In the case of the Pd foil, the FT peaks of metallic Pd were attributed to four Pd-Pd shells with distances of 2.74, 3.86, 4.78, and $5.40 \AA$. The major peak corresponds to about twelve Pd atoms at a Pd-Pd interatomic distance of $2.74 \pm 0.02 \AA$ as reported by Polizzi et al. (2001).

The EXAFS spectra of both low-Ru and high-Ru biogenic NPs samples are characterized by the presence of two Pd species: one metallic ( $\mathrm{Pd}-\mathrm{Pd})$ and two complexed $(\mathrm{Pd}-\mathrm{O})$ via oxygen atoms to the cell matrix functional groups. For the $\mathrm{Pd}-\mathrm{O}_{1}$ and $\mathrm{PdO}_{2}$ phases, the distances found are comparable to the ones of palladium oxide $[\mathrm{Pd}(\mathrm{II}) \mathrm{O}]$ with a simple tetragonal structure (Borowski, 1997) with $\mathrm{Pd}-\mathrm{O}_{1}$ contributions at $2.1 \pm 0.02 \AA$ and $2.04 \pm 0.02 \AA$ for high-Ru and low-Ru samples, respectively, and to $\mathrm{Pd}-\mathrm{O}_{2}$ bond distance at $2.55 \pm 0.02 \AA$. The distances were calculated using the Pd-O backscattering phase and amplitude functions obtained from PdO crystal structure using the FEFF8 program. The oxygen atoms could have originated from the carboxyl groups of, e.g., aspartic and glutamic acids of the bacterial cells as reported by Fahmy et al., 2006. The interatomic distances obtained for metallic phase contribution were very close to the ones of the metallic foil.

\section{EXAFS: Ru K-Edge}

Figure 5B shows the Ru K-edge EXAFS spectra of a ruthenium foil, $\mathrm{RuO}_{2}, \mathrm{RuCl}_{3}$, low-Ru, high- $\mathrm{Ru}$, and $\mathrm{Ru}$-only samples along with their corresponding Fourier transforms (FT). The structural parameters of the calculated spectra are summarized in Table 3.
A

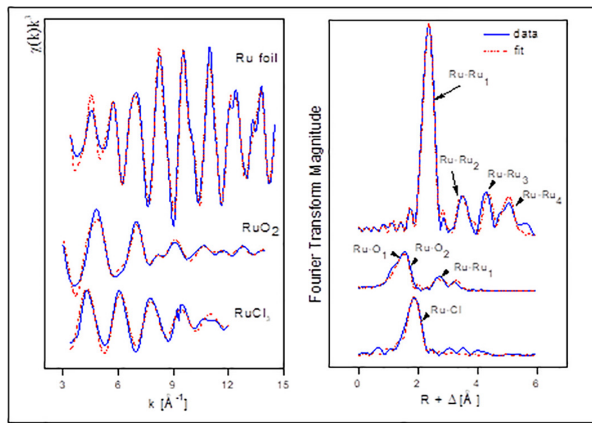

B
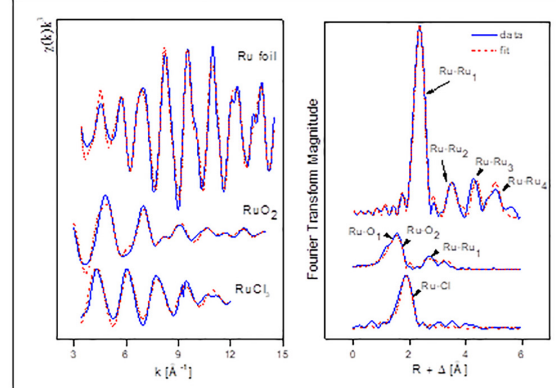
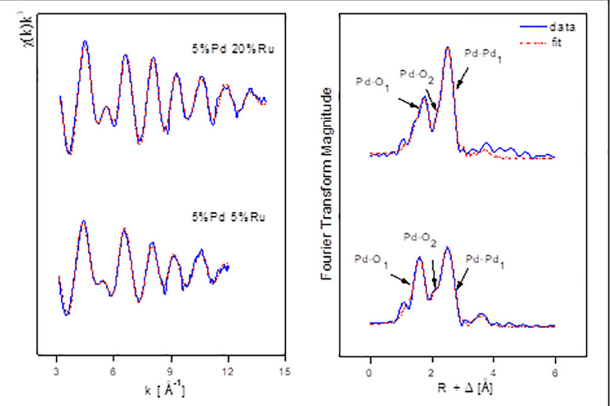

FIGURE 5 | (A) EXAFS spectra of Pd foil and Pd-Ru biogenic NPs samples as well as their corresponding FT. (B) EXAFS spectra of Ru foil, RuCl 3 , and Pd-Ru biogenic NPs samples as well as their corresponding FT. 
TABLE 2 | EXAFS structural parameters of the palladium foil and biogenic Pd-Ru NPs.

\begin{tabular}{|c|c|c|c|c|c|}
\hline Sample & Shell & $\mathbf{N}^{\mathbf{a}}$ & $R(\AA ̊)$ & $\sigma^{2}\left(\AA^{2}\right)^{c}$ & $\Delta E(e V)$ \\
\hline \multirow[t]{4}{*}{ Pd foil* } & $\mathrm{Pd}-\mathrm{Pd}_{1}$ & $12^{d}$ & 2.74 & 0.0047 & -0.66 \\
\hline & $\mathrm{Pd}-\mathrm{Pd}_{2}$ & $6^{e}$ & 3.86 & 0.0086 & \\
\hline & $\mathrm{Pd}-\mathrm{Pd}_{3}$ & $24^{e}$ & 4.78 & 0.0083 & \\
\hline & $\mathrm{Pd}-\mathrm{Pd}_{4}$ & $12^{\mathrm{e}}$ & 5.40 & 0.0055 & \\
\hline \multirow[t]{4}{*}{$5 \% \mathrm{Pd} 20 \% \mathrm{Ru}$} & $\mathrm{Pd}-\mathrm{O}_{1}$ & $1.8 \pm 0.3$ & 2.10 & 0.0076 & 23.2 \\
\hline & $\mathrm{Pd}-\mathrm{O}_{2}$ & $1.2 \pm 0.1$ & 2.55 & $0.0076^{e}$ & 2.62 \\
\hline & $\mathrm{Pd}-\mathrm{Pd}_{1}$ & $3.2 \pm 0.4$ & 2.75 & 0.0084 & \\
\hline & $\mathrm{Pd}-\mathrm{Pd}_{2}$ & $1.6^{\mathrm{e}}$ & 3.85 & 0.013 & \\
\hline \multirow[t]{4}{*}{$5 \% \operatorname{Pd} 5 \% \mathrm{Ru}$} & $\mathrm{Pd}-\mathrm{O}_{1}$ & $1.5 \pm 0.2$ & 2.04 & 0.0059 & 14.5 \\
\hline & $\mathrm{Pd}-\mathrm{O}_{2}$ & $1.0 \pm 0.1$ & 2.55 & $0.0059^{e}$ & -1.56 \\
\hline & $\mathrm{Pd}-\mathrm{Pd}_{1}$ & $3.2 \pm 0.3$ & 2.75 & 0.011 & \\
\hline & $\mathrm{Pd}-\mathrm{Pd}_{2}$ & $1.6^{\mathrm{e}}$ & 3.83 & 0.014 & \\
\hline
\end{tabular}

${ }^{a}$ Errors in coordination numbers are $\pm 25 \%$ and standard deviations as estimated by EXAFSPAK; ${ }^{b}$ errors in distance are $\pm 0.02 \AA ;{ }^{c}$ Debye-Waller factor; ${ }^{d}$ fixed for calculation; ${ }^{e}$ Coordination number $(N)$ linked to the $N$ of $P d-P d_{1}$ path or to $P d-$ $\mathrm{O}_{1} \cdot{ }^{*}$ Supplementary Figure S7.

TABLE 3 | EXAFS structural parameters of the ruthenium foil, $\mathrm{RuO}_{2}, \mathrm{RuCl}_{3}$ and biogenic Ru and Pd-Ru NPs samples

\begin{tabular}{|c|c|c|c|c|c|}
\hline Sample & Shell & $\mathrm{N}^{\mathrm{a}}$ & $R(\AA))^{b}$ & $\sigma^{2}\left(\AA^{2}\right)^{c}$ & $\Delta E(e V)$ \\
\hline \multirow[t]{4}{*}{ Ru foil* } & $R u-R u_{1}$ & $12^{\mathrm{d}}$ & 2.67 & 0.004 & -1.81 \\
\hline & $\mathrm{Ru}-\mathrm{Ru}_{2}$ & $6^{d}$ & 3.78 & 0.0028 & \\
\hline & $\mathrm{Ru}-\mathrm{Ru}_{3}$ & $24^{d}$ & 4.68 & 0.0084 & \\
\hline & $\mathrm{Ru}-\mathrm{Ru}_{4}$ & $12^{\mathrm{d}}$ & 5.35 & 0.0031 & \\
\hline $\mathrm{RuCl}_{3}$ & $\mathrm{Ru}-\mathrm{Cl}$ & $5.3 \pm 0.3$ & 2.35 & 0.0059 & -2.7 \\
\hline \multirow[t]{4}{*}{$\mathrm{RuO}_{2}$} & $\mathrm{Ru}-\mathrm{O}_{1}$ & $2^{d}$ & 1.87 & 0.002 & 1.80 \\
\hline & $\mathrm{Ru}-\mathrm{O}_{2}$ & $4^{d}$ & 1.99 & 0.002 & \\
\hline & $R u-R u_{1}$ & $2^{d}$ & 3.09 & 0.0068 & \\
\hline & $\mathrm{Ru}-\mathrm{Ru}_{2}$ & $8^{d}$ & 3.56 & 0.016 & \\
\hline \multirow[t]{3}{*}{$5 \% \mathrm{Ru}$} & $\mathrm{Ru}-\mathrm{O}_{1}$ & $1.1 \pm 0.1$ & 1.96 & 0.001 & 7.5 \\
\hline & $\mathrm{Ru}-\mathrm{O}_{2}$ & $2.5 \pm 0.2$ & 2.1 & $0.001^{d}$ & \\
\hline & $R u-R u$ & $0.5 \pm 0.1$ & 2.85 & 0.01 & \\
\hline \multirow[t]{3}{*}{$5 \% \operatorname{Pd} 20 \% \mathrm{Ru}$} & $\mathrm{Ru}-\mathrm{O}_{1}$ & $1.8 \pm 0.4$ & 2.04 & 0.001 & 8.6 \\
\hline & $\mathrm{Ru}-\mathrm{O}_{2}$ & $1.4 \pm 0.3$ & 2.16 & $0.001^{d}$ & \\
\hline & $R u-R u$ & $1.0 \pm 0.2$ & 2.77 & 0.0012 & \\
\hline \multirow[t]{3}{*}{$5 \% \mathrm{Pd} 5 \% \mathrm{Ru}$} & $\mathrm{Ru}-\mathrm{O}_{1}$ & $1.8 \pm 0.1$ & 1.98 & 0.002 & 7.4 \\
\hline & $\mathrm{Ru}-\mathrm{O}_{2}$ & $1.8 \pm 0.2$ & 2.15 & 0.002 & \\
\hline & $R u-R u$ & $2.0 \pm 0.5$ & 2.77 & 0.019 & \\
\hline
\end{tabular}

a Errors in coordination numbers are $\pm 25 \%$ and standard deviations as estimated by EXAFSPAK; berrors in distance are $\pm 0.02 \AA$; ${ }^{c}$ DebyeWaller factor; ${ }^{d}$ Coordination number $(N)$ linked to the $N$ of $R u-O_{1}$ path. * Supplementary Figure S7.

The FT of the three experimental samples was well fitted by the use of two Ru-O bonds with interatomic distances of 1.96-2.04 and 2.1-2.16 $\pm 0.02 \AA$, and a single Ru-Ru shell with a bond distance of 2.77-2.85 $\pm 0.02 \AA$. The distances of the shortest $\mathrm{Ru}-\mathrm{O}$ bond (1.96-2.04 $\pm 0.02 \AA$ ) can be assigned to $\mathrm{Ru}=\mathrm{O}$ of $\mathrm{RuO}_{2}$ (McKeown et al., 1999) while the shell at bond distance of 2.1-2.16 $\AA$ is assigned to the $\mathrm{Ru}-\mathrm{O}_{\text {hydroxo }}(\mathrm{Ru}-\mathrm{OH})$ bond as observed in $\mathrm{RuNi}(\mathrm{OH})_{2}$ composite (Venkatesan et al., 2009). The EXAFS spectra include also a Ru-Ru shell with a bond distance of about 2.77-2.85 $\pm 0.02 \AA$. The higher Debye-Waller factor of this shell (0.01-0.019 $\left.\AA^{2}\right)$ indicates that there is probably a wide spread of $\mathrm{Ru}-\mathrm{Ru}$ distances with an averaged value of $2.77-2.85 \pm 0.02 \AA$. This implies the possible contribution of $\mathrm{Ru}-\mathrm{Ru}$ arising from two different ligands ( $\mathrm{Ru}$ metal and $\mathrm{RuO}_{2}$ ). This assumption is supported by two features: (1) the bond distance value of $2.77-2.85 \pm 0.02 \AA$ could correspond to the average distance of $\mathrm{Ru}-\mathrm{Ru}$ from $\mathrm{Ru}$ metal $(2.66 \pm 0.02 \AA)$ and from $\mathrm{RuO}_{2}(3.09 \pm 0.02 \AA)$ obtained for reference compounds (Table 3). These two shells were not represented as separate shells in the FT spectra since their distances span an $R$ range that was not large enough to be differentiated as individual peaks in an EXAFS spectrum for which $\Delta k=7 \AA^{-1}$ in agreement with $\Delta R \geq \pi /(2 \Delta k)$ (Merroun et al., 2005); (2) the linear combination fitting results of the XANES spectra suggested the presence of low amounts of $\mathrm{Ru}$ metal in addition to $\mathrm{Ru}(\mathrm{III})$ and $\mathrm{Ru}(\mathrm{IV})$ species (see above).

However, since catalysis would be largely confined to the surfaces of the cells the bulk signal could mask the contributions of the cell surface components, placing minor surface-located species below the level of detection. Hence, the metal composition of the cell surface was investigated using XPS. This surface method probes only the outermost $\sim 10 \mathrm{~nm}$ of the structure, i.e., the depth of the outer membrane and outermost region of the periplasmic space.

\section{Examination of Cell Surface Bio-Ru and Bio-Pd/Ru by X-Ray Photoelectron Spectroscopy}

The surface-bound NPs of whole cells (the outermost $\sim 10 \mathrm{~nm}$ of the cell wall) were examined by XPS, where the reduction of $\mathrm{Pd}(\mathrm{II})$ to $\operatorname{Pd}(0)$ in the "seeding" step was confirmed previously (Omajali, 2015; Omajali et al., 2017). The wide energy spectrum for all samples is shown in Figure 6A. All samples clearly evidenced the presence of the $\mathrm{C} 1 \mathrm{~s}+\mathrm{Ru} 3 \mathrm{~d}$ peak along with the oxygen $\mathrm{O} 1 \mathrm{~s}$ signal centered at $\sim 285$ and $\sim 530 \mathrm{eV}$, respectively. Apart from these, the nitrogen $\mathrm{N}$ $1 \mathrm{~s}, \mathrm{Ru} 3 \mathrm{p}$ and, where applicable, low intensity signals of $\mathrm{Pd}$ $3 \mathrm{~d}$ signals were also identified. The spectrum for commercial $\mathrm{RuCl}_{3}$ salt (the starting material) is shown in Supplementary Figure $\mathbf{S 8}$ for reference, evidencing $\mathrm{Ru}(\mathrm{III})$ as $\mathrm{RuCl}_{3}$ and $\mathrm{Ru}(\mathrm{OH})_{3}$ species.

Figure 6B shows a comparison of the high resolution Pd 3d spectra for low-Ru and high-Ru bimetallic samples. Resolved and fitted components for the two samples are shown in Figures 6C,D, respectively. The spectra were fitted using Gaussian peaks to identify the oxidation states of Pd. In low-Ru samples, $\mathrm{Pd}$ was found in its native $\mathrm{Pd}(0)$ and oxidized $\mathrm{Pd}(\mathrm{II})$ and also $\mathrm{Pd}(\mathrm{IV})$ states; Table 4 lists the respective binding energies (Liu et al., 2015; Priestley et al., 2015). However, high- $\mathrm{Ru}$ samples revealed a very noisy Pd signal (Figure 7D), which has not been resolved into components. However, it can be stated with confidence that at least two components $\operatorname{Pd}(0)$ and oxidized $\operatorname{Pd}(\mathrm{II})$ are present in these samples. The weak Pd 3d signals could be suggestive of the relatively large amount of Pd internalized by the cells (Figures 2, 3) resulting 

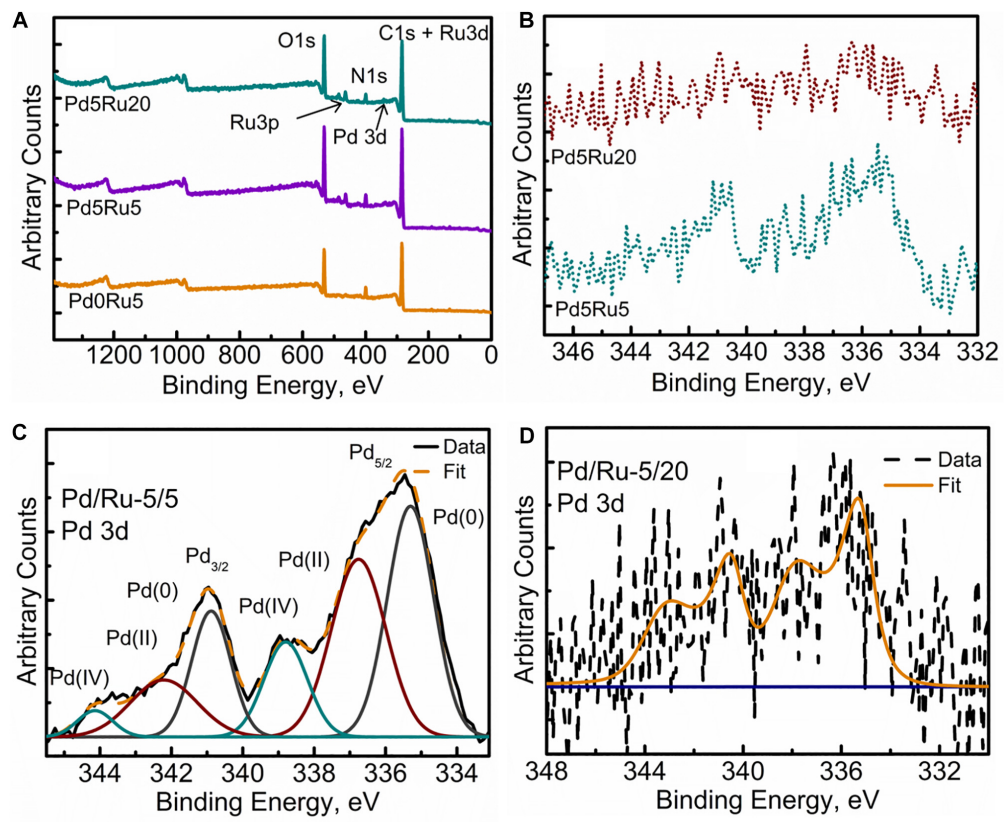

FIGURE 6 |XPS spectra of (A) Wide Energy Survey Spectra (WESS) for all three samples, (B) high resolution Pd 3d spectra, and fitted components for (C) Low Pd and Ru loading sample and (D) low Pd high Ru loading sample.

TABLE 4 | XPS peak positions for the various components identified in the high resolution elemental spectra.

\begin{tabular}{|c|c|c|c|}
\hline & \multicolumn{3}{|c|}{$\begin{array}{l}\text { Binding energies as recorded for different } \\
\text { samples, eV }\end{array}$} \\
\hline & $5 \% \mathbf{R u}$ & $5 \% \mathrm{Pd} 5 \% \mathrm{Ru}$ & $5 \% \operatorname{Pd} 20 \% \mathrm{Ru}$ \\
\hline \multicolumn{4}{|l|}{ C1 s } \\
\hline $\mathrm{C}-\mathrm{C} / \mathrm{C}-\mathrm{H}$ & 284.8 & 284.8 & 284.8 \\
\hline C-OH/amine & 285.7 & 286.0 & 286.1 \\
\hline $\mathrm{C}=\mathrm{O} /$ amide & 287.5 & 287.5 & 288.0 \\
\hline $\mathrm{COOH}$ & 288.8 & 288.7 & 288.8 \\
\hline \multicolumn{4}{|l|}{ Ru3d } \\
\hline $\mathrm{RuO}_{2} / \mathrm{Ru}$-ligand & $281.0,286.3$ & $280.7,285.2$ & $280.9,285.6$ \\
\hline $\mathrm{Ru}(\mathrm{OH})_{3}$ & $281.9,286.7$ & $281.7,286.3$ & $281.7,286.5$ \\
\hline $\mathrm{RuCl}_{3}$ & - & $282.3,286.7$ & $282.6,287.0$ \\
\hline $\mathrm{Ru}-\mathrm{NO}$ & 283.3, 287 & 283.3, 287.1 & $283.2,287.5$ \\
\hline \multicolumn{4}{|l|}{ Pd3d } \\
\hline $\mathrm{Pd}(0)$ & - & $335.3,340.8$ & - \\
\hline $\operatorname{Pd}(I I)$ & - & $336.7,342.2$ & - \\
\hline $\mathrm{P}(\mathrm{IV})$ & - & $338.7,344.1$ & - \\
\hline \multicolumn{4}{|l|}{$01 s$} \\
\hline $\mathrm{Me}-\mathrm{Ox}$ & 529.6 & 529.8 & 529.8 \\
\hline $\mathrm{O}=\mathrm{C} /$ sulfates & 531.0 & 531.2 & 531.3 \\
\hline $\mathrm{O}-\mathrm{C} / \mathrm{O}-\mathrm{N}$ & 532.2 & 532.1 & 532.4 \\
\hline $\mathrm{O}-\mathrm{C}$ (phenolic) $/ \mathrm{SiO}_{2}$ & 533.2 & 533.2 & 533.3 \\
\hline $\mathrm{H}_{2} \mathrm{O}$ ads. & 534.4 & 534.4 & 534.5 \\
\hline
\end{tabular}

in minimal Pd nanoparticle formation near the bacterial outer membrane and outermost wall layers which are within the sampling depth of XPS.
Figure 7A shows the comparison of $\mathrm{C} 1 \mathrm{~s}+\mathrm{Ru} 3 \mathrm{~d}$ high-resolution spectra for all three bio-NP samples. Figures 7B-D show, respectively, low-Ru and high-Ru samples, and Figure $\mathbf{7 B}$ the Ru-only sample. The high-resolution C1 $s$ spectra for $E$. coli has been previously resolved into four components identified as C-C $(284.5 \mathrm{eV}), \mathrm{C}-\mathrm{OH} /$ amine $(286 \mathrm{eV})$, $\mathrm{C}=\mathrm{O} /$ amide $(288 \mathrm{eV})$, and $\mathrm{COOH}(290 \mathrm{eV})$, respectively (Priestley et al., 2015). The introduction and growth of metal NPs in the bacterial biomass (Figures $7 \mathbf{B}-\mathbf{D}$ ) revealed a significant change in the spectra, suggesting some loss of $\mathrm{C}=\mathrm{O} /$ amide and $\mathrm{C}-\mathrm{OH} /$ amine groups along with the introduction of various $\mathrm{Ru}$ components. The amount of $\mathrm{Ru}$ contribution to the $\mathrm{C} 1 \mathrm{~s}+\mathrm{Ru} 3 \mathrm{~d}$ spectra appears to increase as the metal loading increases (from $2.6 \mathrm{wt} \% \mathrm{Ru}$ only (Table 1 ) to $5 \% \mathrm{Ru}$ and $5 \% \mathrm{Pd}$ to $5 \% \mathrm{Pd}$ and $20 \% \mathrm{Ru}$ loading, as seen in Figures $7 \mathrm{~B}-\mathrm{D})$. This could suggest an interactive behavior enabling a greater amount of $\mathrm{Ru}$ to stay near the outer bacterial membrane (or limited/reduced uptake of $\mathrm{Ru}$ with increasing $\mathrm{Ru}$ loading), in the presence of $\mathrm{Pd}$ in the system. Specifically, four $\mathrm{C} 1 \mathrm{~s}$ components, namely, C-C/C-OH, $\mathrm{C}$-O/amine, $\mathrm{C}=\mathrm{O} /$ amide, and $\mathrm{COOH}$ were identified/resolved in all three types of metal loaded E. coli samples. Three to four types of Ru doublet components were also resolved in all three metal NPs - bacterial biomass samples (Figures 7B-D). These were attributed to $\mathrm{RuO}_{2}$, (Morgan, 2015) $\mathrm{RuCl}_{3}$, and $\mathrm{Ru}(\mathrm{OH})_{3}$. Further analysis of Ru 3p spectra (Supplementary Figure S9) suggested the possibilities of Ru-ligand complexes forming with aromatic carbon structures and Ru-nitrogen oxide (Ru-NOx) like structures being formed within the biological system. $\mathrm{Ru}$ complexes are known to be formed within cellular structures, as discussed earlier. These components were, therefore, identified in the $\mathrm{Ru} 3 \mathrm{~d}$ spectra, which led to dual attributions, given the 

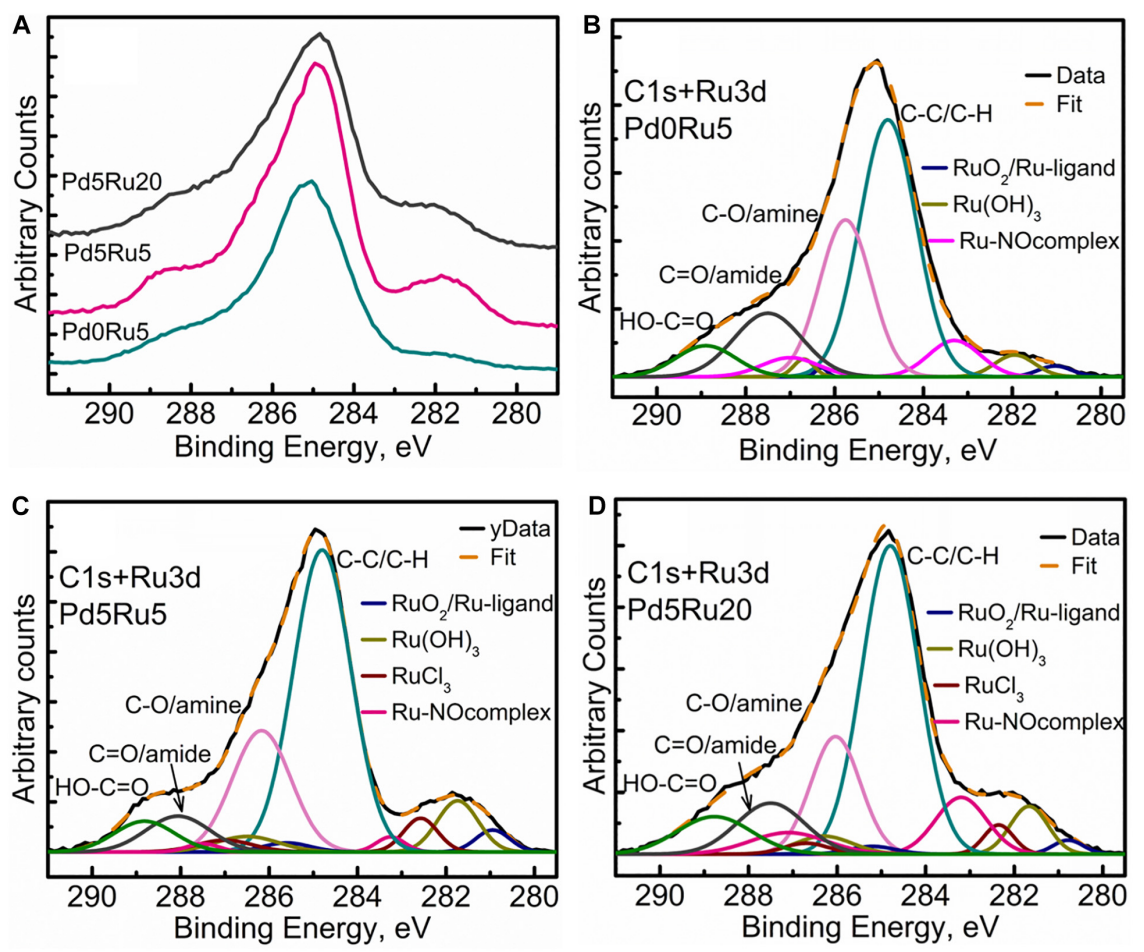

FIGURE 7 | Carbon and Ruthenium XPS spectra showing (A) comparison of high resolution C 1s+Ru 3d region for all three samples, (B) C 1s+Ru 3d peak fitting for low Ru only sample, (C) C 1s+Ru 3d peak fitting for low Pd and low Ru loading sample, (D) C 1s+Ru 3d peak fitting for low Pd and high Ru loading sample.
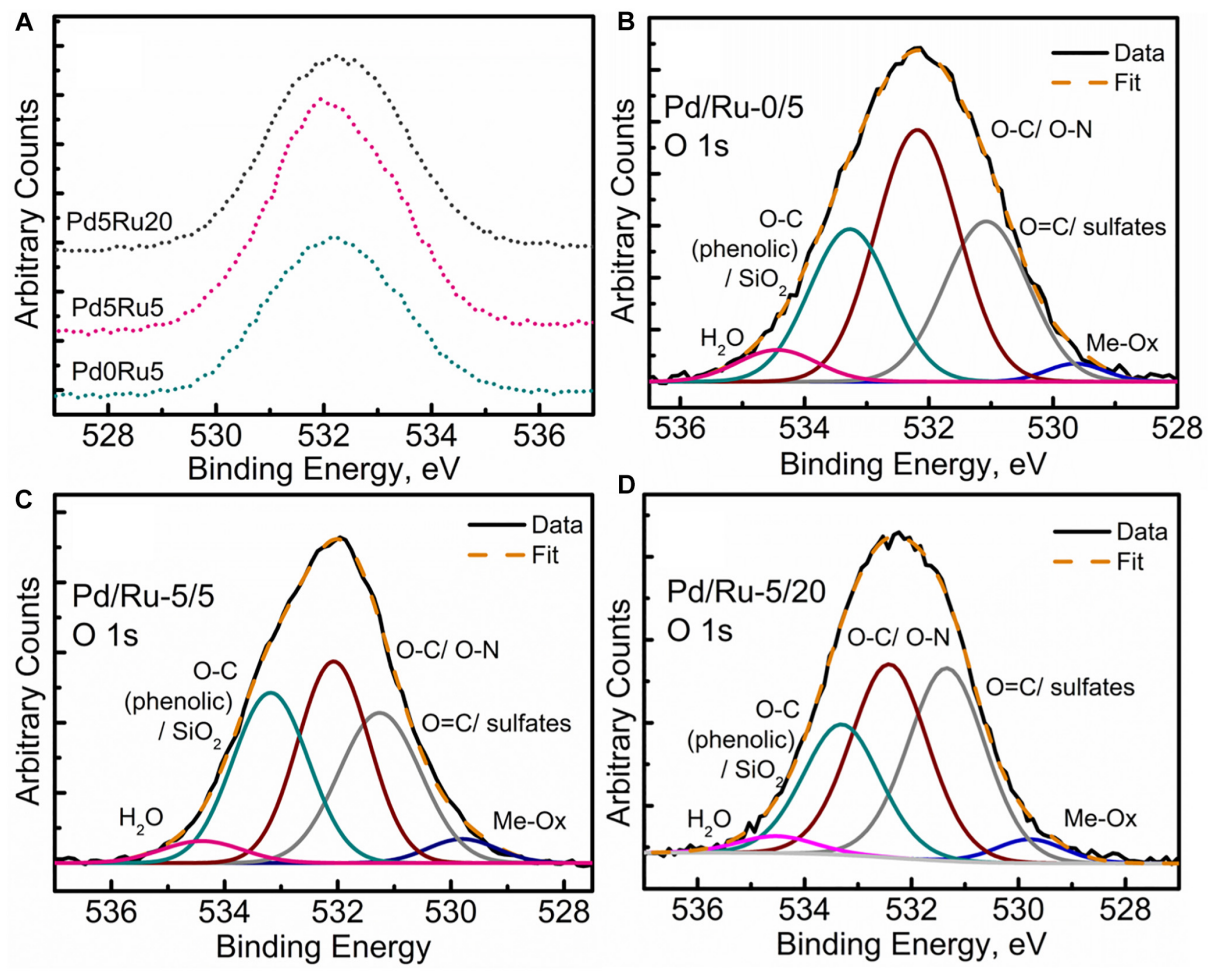

FIGURE 8 | Oxygen XPS spectra showing (A) comparison of high resolution $\mathrm{O}$ 1s region for all three samples, (B) $\mathrm{O}$ 1s peak fitting for low Ru only sample, (C) $\mathrm{O}$ 1s peak fitting for low Pd and low Ru loading sample, (D) $\bigcirc$ 1s peak fitting for low Pd and high Ru loading sample. 
minor shifts in the binding energies (Table 4) in comparison to the literature (Morgan, 2015). The presence of Ru-NOx components corroborated with the $\mathrm{N}$ 1s spectra (not shown). It is worth mentioning that the $\mathrm{RuCl}_{3}$ component could not be distinctly identified in the Ru-only sample. Since this sample has only small quantity of metal added $(2.6 \% \mathrm{Ru}$ only: Table 1$)$ it is possible to have minimal or no $\mathrm{RuCl}_{3}$ residues and maximum uptake and internalization of $\mathrm{Ru}$ into cellular layers beneath the XPS-accessible depth. The slight shift of $\mathrm{Ru}(\mathrm{OH})_{3}$ toward higher binding energy may be due to small residues of $\mathrm{RuCl}_{3}$ which could not be resolved into a distinct peak given the complexity of the $\mathrm{C} 1 \mathrm{~s}+\mathrm{Ru} 3 \mathrm{~d}$ spectra.

The high-resolution $\mathrm{O}$ 1s spectra for all samples can be seen in Figure 8A. Specifically, the deconvolution of $\mathrm{O} 1 \mathrm{~s}$ spectrum into the various components for all three samples (Figures 8B-D) revealed a small component peak at $\sim 529.5 \mathrm{eV}$, suggesting the presence of metal oxides, which is in agreement with the $\mathrm{Pd} 3 \mathrm{~d}$ and $\mathrm{Ru} 3 \mathrm{~d}$ spectra, with the EXAFS analysis (PdO) and with $\mathrm{RuO}_{2}$ evolving from $\mathrm{Ru}(\mathrm{OH})_{3}$ (see earlier). Another observation was the decrease in the $\mathrm{C}-\mathrm{O}$ component and a relative increase in $\mathrm{C}=\mathrm{O} /$ sulfate components as the metallic content increased in the form of Ru-alone and low-Ru and high-Ru bimetallics. This could be due to singly bonded oxygen being sacrificed for metal $(\mathrm{Ru} / \mathrm{Pd})$ oxide formation. A similar trend was also observed for the adsorbed water content peak denoted by the component peak near $534.7 \mathrm{eV}$. The slight loss of adsorbed water content and its possible implication is not very clear. Perhaps it can be suggested that with an increase in the metallic component, the formation of various Ru oxides and complexes was promoted and contributed to by the adsorbed/loosely bound water molecules within the cellular structures. However, the exact nature of such interactions in such a complex system would be difficult to predict within the limitations of this study.

None of the spectra provide sufficient evidence for the occurrence of $\mathrm{Ru}(0)$ as no peaks are visible at $280 \mathrm{eV}$.

\section{Catalytic Activity of the Metallized Cells in the Conversion of 5-HMF to 2,5-DMF}

Most published work has used commercially available substrates but, since one of the goals of this work is to realize resources from wastes, 5-HMF was extracted from hydrolyzates of starch and cellulose made by thermochemical hydrolysis methods, previously developed to yield parallel fermentable and added-value side-streams (see Introduction). The catalysts were therefore tested against commercial 5-HMF and 5-HMF from hydrolyzate extracts in a common solvent (MTHF) for extraction and catalytic upgrading. Preliminary work established that this solvent extracted between 60 and 65\% of the 5-HMF (Orozco, unpublished) but the extraction method was not optimized.

First, commercial $5 \mathrm{wt} \% \mathrm{Ru} / \mathrm{C}$ and $5 \mathrm{wt} \% \mathrm{Pd} / \mathrm{C}$ catalysts were compared in MTHF using commercial 5-HMF. The Ru catalyst gave $100 \%$ conversion of 5 -HMF with $57.1 \%$ selectivity to 2,5-DMF with respective values of 100 and $3.3 \%$ for the $\mathrm{Pd} / \mathrm{C}$ equivalent. Therefore, Pd-only catalysts were not considered further. All catalysts tested (data are shown in Supplementary Table 1) gave close to $100 \%$ conversion of 5-HMF (Figure 9A)

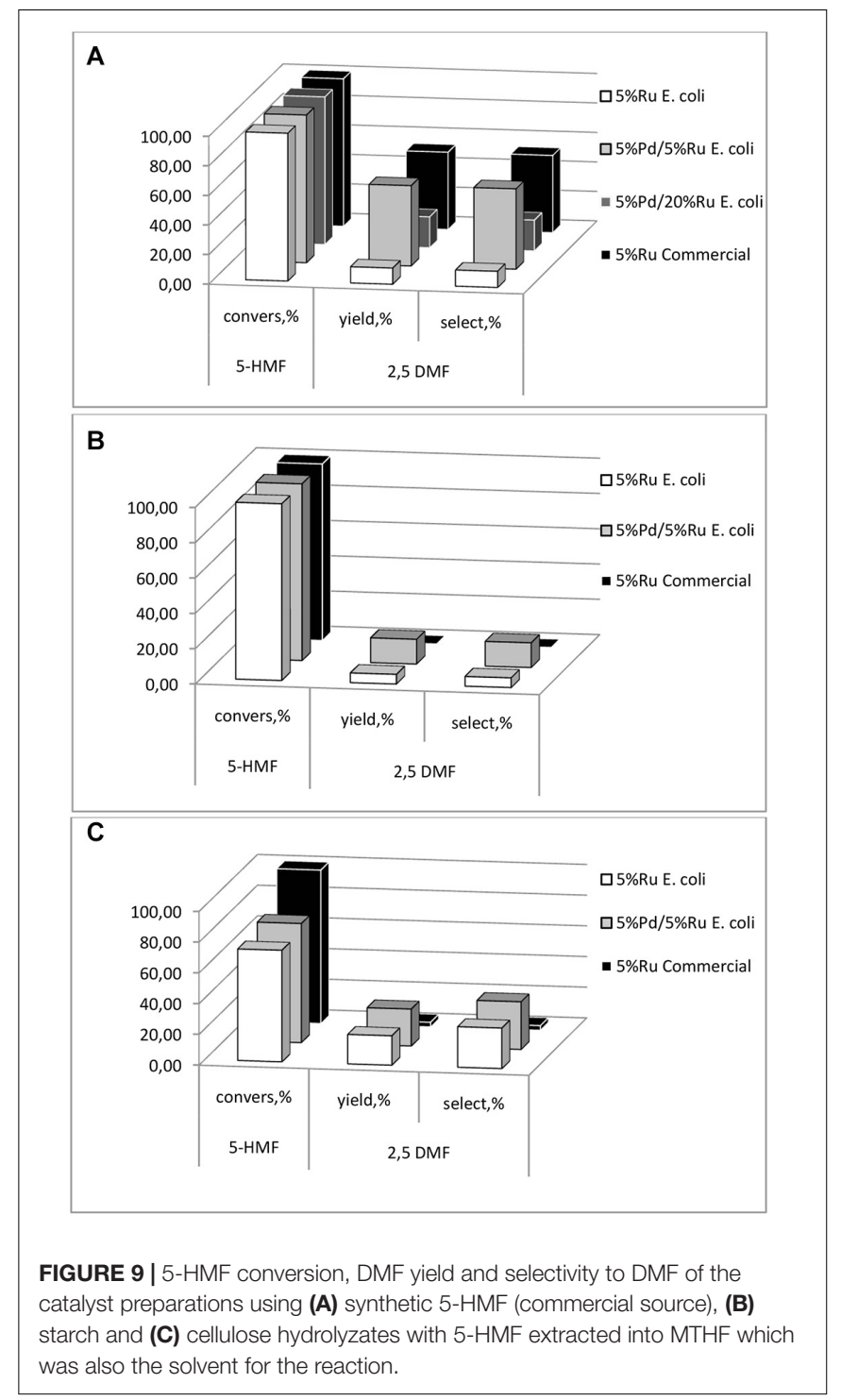

but the high-Ru biomaterial showed a low yield (21\%) and selectivity to 2,5-DMF and this, too, was not considered further. It would seem that the presence of the core-shells in the high-Ru sample confers no benefit but these were few in number as compared to the remainder of the metal NPs (Supplementary Figure S5). Lei et al. (2014) noted an adverse effect of an excess of $\mathrm{Ru}$, attributing this to excessive $\mathrm{Ru}$ accelerating the occurrence of side reactions. Hence further tests compared the low-Ru samples and $5 \mathrm{wt} \%$ bio-Ru.

Using pure 5-HMF the bio-Ru was less effective than the commercial 5 wt $\% \mathrm{Ru} / \mathrm{C}$ catalyst ( $\sim 10 \%$ selectivity) whereas the low-Ru bimetallic and commercial catalyst gave similar results ( $>50 \%$ selectivity: Figure 9A). However, notably the commercial $\mathrm{Ru} / \mathrm{C}$ catalyst had little activity against 5-HMF made from the starch or cellulose (Figures $\mathbf{9 B}, \mathbf{C}$ ). It is possible that residual polymeric components fouled the commercial catalyst (co-extracted into the MTHF), or that catalyst poisons were made via the thermochemical hydrolysis reactions, but this was 
not tested and assumes that these adverse components were co-extracted into MTHF. An alternative explanation is that the chemical catalyst was over active in this reaction, proceeding into additional by-products. An example of the product mix is shown in Supplementary Information (Supplementary Figure S10). In each case (Figures 9B,C) the $5 \mathrm{wt} \% \mathrm{Pd} / 5 \mathrm{wt} \% \mathrm{Ru}$ bio-catalyst achieved significant production of 2,5-DMF and, in the case of cellulose hydrolysate, the Ru-only bio-catalyst became comparable to the low-Ru bimetallic (c.f. Figure 9A). A detailed investigation of the reaction pathway was beyond this scoping study and is in progress but clearly the bio-derived catalyst is able to compete effectively with commercial catalyst against pure 5-HMF and outperforms the latter in conversion of 5-HMF from actual hydrolyzates.

\section{CONCLUSION}

This study shows clearly that bio- $\mathrm{Pd} / \mathrm{Ru}$ catalyst (5 wt $\%$ of each metal) has potential in the production of 2,5-DMF from 5-HMF from biomass hydrolyzate, which is not achieved using a commercial counterpart. This study reports the formation of $\mathrm{Pd} / \mathrm{Ru}$ core shell structures in an analogous way to those of $\mathrm{Pd} / \mathrm{Au}$ reported previously but these may contribute little overall to the outcome since the dominance of the non-core-shell excess $\mathrm{Ru}$ in the high- $\mathrm{Ru}$ material is counterproductive to 2,5-DMF selectivity. It is far from clear what metal species (or combination of them) actually catalyzes the reaction; evidence was found for various valences of both metals but not, equivocally for $\mathrm{Ru}(0)$ whereas $\mathrm{Ru}(\mathrm{IV})$ was evident (as $\mathrm{RuO}_{2}$ ) [along with $\mathrm{Pd}(\mathrm{O})$ and $\mathrm{Pd}(0)$ and also $\mathrm{Pd}(\mathrm{IV})]$. The metal speciation is important, e.g., the degree of $\mathrm{Ru}$ oxidation was found to influence the catalytic activity in bimetallic Pt/Ru nanoparticles (Wang et al., 2016). It is likely that heterogeneous NPs are produced since the bacterial cell surface offers a variety of ligands to initiate the nucleation of $\mathrm{Pd}(\mathrm{II})$ (and also sites that would complex with incoming $\mathrm{Ru}(\mathrm{III})$ ) and NP evolution may also be influenced by the surrounding biochemical matrix as well as oxygen ingress during catalyst storage in air. Future work would use systems biology approaches to "dissect" the microbial features that contribute to, and steer, metallic NP development. Initial steps have been taken in the case

\section{REFERENCES}

Abramoff, M. D., Magalhaes, P. J., and Ram, S. J. (2004). Image processing with Image. J. Biophotonics Int. 11, 36-42.

Ankudinov, A. L., Ravel, B., Rehr, J. J., and Conradson, S. D. (1998). Realspace multiple-scattering calculation and interpretation of X-ray absorption near-edge spectra. Phys. Rev. B 58, 7565-7575. doi: 10.1103/PhysRevB.58.7565

Bennett, A. J., Mikheenko, I. P., Deplanche, K., Shannon, I. J., Wood, J., and Macaskie, L. E. (2013). Nanoparticles of palladium supported on bacterial biomass: new re-usable heterogeneous catalyst with comparable activity to homogeneous colloidal Pd in the Heck reaction. Appl. Catal. B Environ. 140141, 700-707. doi: 10.1016/j.apcatb.2013.04.02.2

Blumenthal, L. C., Jens, C. M., Ulbrich, J., Schwering, J. F., Langrehr, V., Turek, T., et al. (2016). Systematic identification of solvents optimal for the extraction of 5-hydroxymethylfurfural from aqueous reactive solutions. ACS Sustain. Chem. Eng. 4, 228-235. doi: 10.1021/acssuschemeng.5601036 of monometallic Pd-NPs (Torgeman, 2017) that would underpin understanding of bimetallic systems following $\operatorname{Pd}(0)$ nucleation.

\section{AUTHOR CONTRIBUTIONS}

JG-B and IM made and characterized the biomaterials. RO developed the method for 5-HMF extraction from hyrolyzates. RO and JG-B did catalytic testing, with analysis of products by RH. JG-B and MM performed the high resolution SEM/TEM/elemental mapping. MW acquired the XPS. MW and SS performed the XPS interpretations. DB performed the EXAFS measurements with interpretation by MM. The manuscript was authored by LM with all authors contributing to manuscript preparation.

\section{FUNDING}

The project was funded by NERC grant NE/L014076/1 to LM (Program: "Resource Recovery from Wastes"). The Science City Photoemission Facility used in this research was funded through the Science Cities Advanced Materials Project 1: "Creating and Characterizing Next Generation of Advanced Materials" with support from AWM and ERDF funds. The microscopy work was conducted at "Centro de Instrumentación Cientifica" at the University of Granada, Spain.

\section{ACKNOWLEDGMENTS}

The authors thank Dr. Daniel Lester for permitting them to use GC-FID/GC-MS in the Polymer Characterization Research Technology Platform, University of Warwick.

\section{SUPPLEMENTARY MATERIAL}

The Supplementary Material for this article can be found online at: https://www.frontiersin.org/articles/10.3389/fmicb. 2019.01276/full\#supplementary-material

Borowski, M. (1997). Size determination of small Cu-Clusters by EXAFS. J. Phys. IV France 7, C2-C259.

Boucher, M. B., Zugic, B., Cladaras, G., Kammert, J., Marcinkowski, M. D., Lawton, T. J., et al. (2013). Single atom alloy surface analogs in Pd0.18Cu15 nanoparticles for selective hydrogenation reactions. Phys. Chem. Chem. Phys. 15, 12187-12196. doi: 10.1039/C3CP51 $538 \mathrm{~A}$

Castro, L., Blazquez, M., Munoz, J. A., Gonzalez, F. G., and Ballester, A. (2014). Mechanism and applications of metal nanoparticles prepared by bio-mediated process. Rev. Adv. Sci. Eng. 3, 1-18. doi: 10.1166/rase.2014.1064

Charlot, G. (1978). Dosages Absorptiométriques des Eléments Mineraux. 2nd Edn. Paris: Masson.

Courtney, J., Deplanche, K., Rees, N., and Macaskie, L. E. (2016). Biomanufacture of nano- $\mathrm{Pd}(0)$ by Escherichia coli and electrochemical activity of bio- $\mathrm{Pd}(0)$ made at the expense of $\mathrm{H} 2$ and formate as electron donors. Biotechnol. Lett. 38, 1903-1910. doi: 10.1007/s10529-016-2183-3 
De Corte, S., Hennebel, T., De Gusseme, B., Verstraete, W., and Boon, N. (2012). Bio-palladium: from metal recovery to catalytic applications. Microb. Biotechnol. 5, 5-17. doi: 10.1111/j.1751-7915.2011. 00265

Deplanche, K. (2008). New Nanocatalysts Made by Bacteria from Metal Solutions and Recycling of Metal Wastes. PhD Thesis. Birmingham: University of Birmingham.

Deplanche, K., Bennett, J., Mikheenko, I., Omajali, J., Wells, A., Meadows, R., et al. (2014). Catalytic activity of biomass-supported Pd nanoparticles: influence of the biological component in catalytic efficacy and potential application in 'green' synthesis of fine chemicals and pharmaceuticals. Appl. Catal. B Environ. 147, 651-665. doi: 10.1016/j.apcatb.2013.09.045

Deplanche, K., Caldelari, I., Mikheenko, I. P., Sargent, F., and Macaskie, L. E. (2010). Involvement of hydrogenases in the formation of highly catalytic $\operatorname{Pd}(0)$ nanoparticles by bioreduction of Pd(II) using Escherichia coli mutant strains. Microbiology 156, 2630-2640. doi: 10.1099/mic.0.036681-0

Deplanche, K., Merroun, M. L., Casadesus, M., Tran, D. T., Mikheenko, I. P., Bennett, J. A., et al. (2012). Microbial synthesis of core/shell gold/palladium nanoparticles for applications in green chemistry. J. R. Soc. Interface 9, 1705-1712. doi: 10.1098/rsif.2012.0003

Deplanche, K., Mikheenko, I. P., Bennett, J. A., Merroun, M. L., Mounzer, H., Wood, J., et al. (2011). Selective oxidation of benzyl-alcohol over biomasssupported Au/Pd bioinorganic catalysts. Topics Catal. 54, 1110-1114. doi: 10. 1007/s11244-011-9691-0

Esparza, R., Santoveña, A., Ruíz-Baltazr, A., Angeles-Pascual, A., Bahena, D., Maya-Cornejo, J., et al. (2017). Study of PtPd bimetallic nanoparticles for fuel cell applications. Mater. Res. 20, 1193-1200. doi: 10.1590/1980-5373-mr-20160934

Fahmy, K., Merroun, M., Pollmann, K., Raff, J., Savchuk, O., Hennig, C., et al. (2006). Secondary structure and $\mathrm{Pd}(\mathrm{II})$ coordination in S-layer proteins from Bacillus sphaericus studied by infrared and X-ray absorption spectroscopy. Biophys. J. 91, 996-1007. doi: 10.1529/biophysj.105.079137

Fairley, N. (2013). CasaXPS. Available at: www.casaxps.com (accessed November $10,2018)$.

Gao, F., and Goodman, D. W. (2012). Pd-Au bimetallic catalysts: understanding alloy effects from planar models and (supported) nanoparticles. Chem. Soc. Rev. 41, 8009-8020. doi: 10.1039/C2CS35160A

Ghosh, D., and Chen, S. (2008). Solid-state electronic conductivity of ruthenium nanoparticles passivated by metal-carbon covalent bonds. Chem. Phys. Lett. 465, 115-119. doi: 10.1016/j.cplett.2008.09.066

Gomez-Bolivar, J., Mikheenko, I. P., Macaskie, L. E., and Merroun, M. L. (2019). Characterization of palladium nanoparticles produced by healthy and microwave-injured cells of Desulfovibrio desulfuricans and Escherichia coli. Nanomaterials 9:857. doi: 10.3390/nano9060857

Hansen, T. S., Barta, K., Anastas, P. T., Ford, P. C., and Riisager, A. (2012). One-pot reduction of 5-hydroxymethylfurfural via hydrogen transfer from supercritical methanol. Green Chem. 14, 2457-2461. doi: 10.1039/C2GC35 $667 \mathrm{H}$

Hosseinkhani, B., Søbjerg, L. S., Rotaru, A. E., Emtiazi, G., Skrydstrup, T., and Meyer, R. L. (2012). Microbially supported synthesis of catalytically active bimetallic Pd-Au nanoparticles. Biotechnol. Bioeng. 109, 45-52. doi: 10.1002/ bit. 23293

Karatzos, S., McMillan, J. D., and Saddler, J. N. (2014). The Potential and Challenges of Drop-in Biofuels. Report T39, ISBN 978-1-910154-07-6. Paris: IEA: Bioenergy Energy Technology Network.

Kim, Y. D., Schwegmann, S., Seitsonen, A. P., and Over, H. (2001). Epitaxial growth of RuO2 (100) on $\mathrm{Ru}$ (0101): surface structure and other properties. J. Phys. Chem. B 105, 2205-2211. doi: 10.1021/jp003650y

Kulkarni, M., and Maddapur, U. (2014). Biosynthesis of metal nanoparticles: a review. J. Nanotechnol. 2014, 510246. doi: 10.1155/2014/510246

Kunwar, B., Deilami, S. D., Macaskie, L. E., Wood, J., Biller, P., and Sharma, B. K. (2017). Nanoparticles of palladium supported on bacterial biomass for hydroprocessing bio oil from continuous hydrothermal liquefaction (NTL) of algae. Fuel 209, 449-456. doi: 10.1016/j.fuel.2017.08.007

Kyriakou, G. K., Boucher, M. B., Jewell, A. D., Lewis, E. A., Lawton, T. J., Baber, A. E., et al. (2012). Isolated metal atom geometries as a strategy for selective heterogeneous hydrogenations. Science 335, 1209-1212. doi: 10.1126/science. 1215864
Lei, H., Tang, X., Xu, J., Wu, Z., Lu, L., and Liu, S. (2014). Selective transformation of 5-hydroxymethylfurfural into the liquid fuel 2,5-dimethylfuran over carbonsupported ruthenium. Ind. Eng. Chem. Res. 53, 3056-3064. doi: 10.1021/ ie404441a

Leng, X., Zou, J., Xiong, X., and He, H. (2014). Hydrothermal synthesis and pseudo capacitance behavior of a highly homogeneous dispersed graphene sheets/ruthenium oxide nanocomposite. RSC Adv. 4, 61596-61603. doi: 10. 1039/C4RA10321A

Lima, A. P., Pereira, F. C., Almeida, M. A. P., Mello, F. M. S., Pires, W. C., Pinto, T. M., et al. (2014). Cytoxicity and apoptotic mechanism of ruthenium(II) amino acid complexes in sarcoma-180 tumor cells. PLoS One 9:e105865. doi: 10.1371/journal.pone.0105865

Liu, X., Yu, H., and Scott, K. (2015). Preparation and evaluation of a highly stable palladium yttrium platinum core-shell-shell structure catalyst for oxygen reduction reactions. Appl. Catal. B Environ. 162, 593-601. doi: 10.1016/j.apcatb. 2014.07.038

Liu, Z., Zhang, X., and Tay, S. W. (2012). Nanostructured PdRu/C catalysts for formic acid oxidation. J. Solid State Electrochem. 16, 545-550. doi: 10.1007/ s10008-011-1378-8

Luo, D., Zhou, B., Li, Zh, Qin, X., Wen, Y., Shi, D., et al. (2018). Biomimetic organization of a ruthenium-doped collagen-based carbon scaffold for hydrogen evolution. J. Mater. Chem. A 6, 2311-2317. doi: 10.1039/ C7TA09493K

Luo, J., Arroyo-Ramirez, L., Gorte, R. J., Tzoulaki, D., and Vlachos, D. G. (2015). Hydrodeoxygenation of $\mathrm{HMF}$ Over $\mathrm{Pt} / \mathrm{C}$ in a continuous flow reactor. AICHE J. 61, 590-597. doi: 10.1002/aic.14660

Luo, W., Sankar, M., Beale, A. M., He, Q., Kiely, C. J., Bruijnincx, P. C. A., et al. (2015). High performing and stable supported nano-alloys for the catalytic hydrogenation of levulinic acid to $\gamma$-valerolactone. Nat. Commun. 6:6549. doi: $10.1038 /$ ncomms 7540

McKeown, D. A., Hagans, P. L., Carette, L. P. L., Russell, A. E., Swider, K. E., and Rolison, D. R. (1999). Structure of hydrous ruthenium oxides:? implications for charge storage. J. Phys. Chem. B 103, 4825-4832. doi: 10.1021/jp990096n

Merroun, M. L., Raff, J., Rossberg, A., Hennig, C., Reich, T., and Selenska-Pobell, S. (2005). Complexation of uranium by cells and S-layer sheets of Bacillus sphaericus JG-A12. App. Environ. Microbiol. 71, 5542-5553. doi: 10.1128/AEM. 71.9.5532-5543.2005

Mikheenko, I. P., Rousset, M., Dementin, S., and Macaskie, L. E. (2008). Bioaccumulation of palladium by Desulfovibrio fructosivorans wild-type and hydrogenase-deficient strains. Appl. Environ. Microbiol. 74, 6144-6146. doi: 10.1128/AEM.02538-07

Monyoncho, E. A., Ntais, S., Soares, F., Woo, T. K., and Baranova, E. A. (2015). Synergetic effect of palladium-ruthenium nanostructures for ethanol electrooxidation in alkaline media. J. Power Sources 287, 139-149. doi: 10.1016/ j.jpowsour.2015.03.186

Morgan, D. J. (2015). Resolving ruthenium: XPS studies of common ruthenium materials. Surf. Interf. Anal. 47, 1072-1079. doi: 10.1002/sia.5852

Murray, A. J., Zhu, J., Wood, J., and Macaskie, L. E. (2017). A novel biorefinery: biorecovery of precious metals from spent automotive catalyst leachates into new catalysts effective in metal reduction and in the hydrogenation of 2pentyne. Miner. Eng. 113, 102-108. doi: 10.1016/j.mineng.2017.08.011

Murray, A. J., Zhu, J., Wood, J., and Macaskie, L. E. (2018). Biorefining of platinum group metals from model waste solutions into catalytically active bimetallic nanoparticles. Microbial. Biotechnol. 11, 359-368. doi: 10.1111/17517915.13030

Nagpure, A. S., Venugopal, A. K., Lucas, N., Manikandan, M., Thirumalaiswamy, R., and Chilukuri, S. (2015). Renewable fuels from biomass-derived compounds: Ru-containing hydrotalcites as catalysts for conversion of HMF to 2,5-dimethylfuran. Catal. Sci. Technol. 3, 1463-1472. doi: 10.1039/C4CY01376J

Nellist, P. D., and Pennycook, S. J. (2000). The principles and interpretation of annular dark field Z-contrast imaging. Adv. Imaging Electron Phys. 113, 147-203. doi: 10.1016/S1076-5670(00)80013-0

Nishimura, S., Ikeda, N., and Ebitani, K. (2014). Selective hydrogenation of biomass-derived 5-hydroxymethylfurfural (HMF) to 2, 5-dimethylfuran (DMF) under atmospheric hydrogen pressure over carbon supported PdAu bimetallic catalyst. Catal. Today 232, 89-98. doi: 10.1016/j.cattod.2013.10.01

Omajali, J. B. (2015). Novel Bionanocatalysts for Green Chemistry Applications. PhD Thesis. Birmingham: University of Birmingham. 
Omajali, J. B., Gomez-Bolivar, J., Mikheenko, I. P., Sharma, S., Kayode, B., AlDuri, B., et al. (2019). Novel catalytically active Pd/Ru bimetallic nanoparticles synthesized by Bacillus benzeovorans. Sci. Rep. 9:4715. doi: 10.1038/s41598-01940312-3

Omajali, J. B., Hart, A., Walker, M., Wood, J., and Macaskie, L. E. (2017). In-situ catalytic upgrading of heavy oil using dispersed bionanoparticles supported on gram-positive and gram-negative bacteria. Appl. Catal. B Environ. 203, 807-819. doi: 10.1016/j.apcatb.2016.10.074

Omajali, J. B., Mikheenko, I. P., Merroun, M. L., and Macaskie, L. E. (2015). Characterization of intracellular palladium nanoparticles synthesized by Desulfovibrio desulfuricans and Bacillus benzeovorans. J. Nanopart. Res. 17, 264-281. doi: 10.1007/s11051-015-3067-5

Omajali, J. B., Mikheenko, I. P., Overton, T. W., Merroun, M. L., and Macaskie, L. M. (2018). Probing the viability of palladium-challenged bacterial cells using flow cytometry. J. Chem. Technol. Biotechnol. 94, 295-301. doi: 10.1002/jctb. 5775

Orozco, R. L. (2012). Hydrogen Production from Biomass by Integrating Thermochemical and Biological Processes. PhD Thesis. Birmingham: University of Birmingham.

Orozco, R. L., Redwood, M. D., Leeke, G. A., Bahari, A., Santos, R. C. D., and Macaskie, L. E. (2012). Hydrothermal hydrolysis of starch with CO2 and detoxification of the hydrolysates with activated carbon for bio-hydrogen fermentation. Int. J. Hydrogen Energy 37, 6545-6553. doi: 10.1016/j.ijhydene. 2012.01.047

Orozco, R. L., Redwood, M. D., Yong, P., Caldelari, I., Sargent, F., and Macaskie, L. E. (2010). Towards an integrated system for bio-energy: hydrogen production by Escherichia coli and use of palladium-coated waste cells for electricity generation in a fuel cell. Biotechnol. Lett. 32, 1837-1845. doi: 10.1007/s10529010-0383-9

Park, J., Lee, J. W., Ye, B. U., Chun, S. H., Joo, S. H., Park, H., et al. (2015). Structural evolution of chemically- driven $\mathrm{RuO} 2$ nanowires and 3-dimensional design for photo- catalytic applications. Sci. Rep. 5:11933. doi: 10.1038/srep11933

Petkov, V., Prasai, B., Shastri, S., Kim, J.-W., Shan, S., Kareem, H., et al. (2017). Surface atomic structure and functionality of metallic nanoparticles: a case study of Au-Pd nanoalloy catalysts. J. Phys. Chem. C 121, 7854-7866. doi: 10.1021/acs.jpcc.7b00139

Polizzi, S., Riello, P., Balerma, A., and Benedetti, A. (2001). Nanostructure of $\mathrm{Pd} / \mathrm{SiO} 2$ supported catalysts. Phys. Chem. Chem. Phys. 3, 4614-4619. doi: 10. 1039/b105607g

Priestley, R. L., Mansfield, A., Bye, J., Deplanche, K., Jorge, A. B., Brett, D., et al. (2015). Pd nanoparticles supported on reduced graphene- E. coli hybrid with enhanced crystallinity in bacterial biomass. RSC Adv. 5, 84093-84103. doi: 10.1039/C5RA12552A

Qui, J., Zhang, H., Wang, X., Han, H., Liang, C., and Li, C. (2006). Selective hydrogenation of cinnamaldehyde over carbon nanotube supported Pd-Ru catalyst. React. Kinet. Catal. Letts. 88, 269-276. doi: 10.1007/s11144-006-0061

Raja, R., Sankar, G., Hermans, S., Shephard, D. S., Bromley, S., Thomas, J. M., et al. (1999). Preparation and characterisation of a highly active bimetallic (Pd$\mathrm{Ru})$ nanoparticle heterogeneous catalyst. Chem. Commun. 1999, 1571-1572. doi: 10.1039/A901263J

Ravel, B., and Newville, M. (2005). ATHENA, ARTEMIS, HEPHAESTUS: data analysis for X-ray absorption spectroscopy using IFEFFIT. J. Synchrotron Rad. 12, 537-541. doi: 10.1107/S0909049505012719

Román-Leshkov, Y., Barrett, C. J., Liu, Z. Y., and Dumesic, J. A. (2007). Production of dimethylfuran for liquid fuels from biomass-derived carbohydrates. Nature 447, 982-985. doi: 10.1038/nature05923

Singh, O. V. (ed.) (2015). Bio-Nanoparticles Biosynthesis and Sustainable Biotechnological Implications. Hoboken, NJ: John Wiley and Sons.

Singh, S. P., Kim, Y.-J., Zhang, D., and Yang, D. C. (2016). Biological synthesis of nanoparticles from plants and microorganisms. Trends Biotechnol. 34, 588-599. doi: 10.1016/j.tibtech.2016.02.006

Soin, N., Roy, S. S., Mitra, S. K., Thubdat, T., and McLaughlin, J. A. (2012). Nanocrystalline ruthenium oxide dispersed few layered graphene (FLG) nanoflakes as supercapacitor electrodes. J. Mater. Chem. 22, 14944-14950. doi: 10.1039/C2JM31226C

St. John, S., Atkinson, R. W., Unocic, K. A., Unocic, R. R., Zawodzinski, T. A., and Papandrew, A. B. (2015). Platinum and palladium overlayers dramatically enhance the activity of ruthenium nanotubes for alkaline hydrogen oxidation. ACS Catal. 5, 7015-7023. doi: 10.1021/acscatal.5b01432

Torgeman, E. (2017). Biosynthesis of Gold and Palladium Nanoparticles via Bacteria. Master thesis. Oslo: University of Oslo.

Tran, D. T., Jones, I. P., Preece, J. A., Johnston, R. L., Deplanche, K., and Macaskie, L. E. (2012). Configuration of microbially synthesized Pd-Au nanoparticles studied by STEM-based techniques. Nanotechnology 23:055701. doi: 10.1088/ 0957-4484/23/5/055701

van Putten, R. J., van der Waal, J. C., de Jong, E., Rasrendra, C. B., Heeres, H. J., and de Vries, J. G. (2013). Hydroxymethylfurfural, a versatile platform chemical made from renewable resources. Chem. Rev. 113, 1499-1597. doi: $10.1021 / \mathrm{cr} 300182 \mathrm{k}$

Venkatesan, S., Kumar, A. S., Jyh-Fu Lee, J.-F., Chan, T.-S., and Zen, J.-M. (2009). Ruthenium-functionalized nickel hydroxide catalyst for highly e?cient alcohol oxidations in the presence of molecular oxygen. Chem. Commun. 2009, 1912-1914. doi: 10.1039/B900636B

Wang, H., Chen, S., Wang, C., Zhang, K., Liu, D., Haleem, Y. A., et al. (2016). Role of $\mathrm{Ru}$ oxidation degree for catalytic activity in bimetallic Pt/Ru nanoparticles. J. Phys. Chem. C 120, 6569-6576. doi: 10.1021/acs.jpcc. $5 \mathrm{~b} 12267$

Yao, Y., He, D. S., Lin, Y., Feng, X., Wang, Z., Yin, P., et al. (2016). Modulating fcc and hcp ruthenium on the surface of palladium-copper alloy through tunable lattice mismatch. Angew. Chem. Int. Educ. Engl. 55, 5501-5505. doi: 10.1002/ anie. 201601016

Yong, P., Liu, W., Zhang, Z., Beauregard, D., Johns, M. L., and Macaskie, L. E. (2015). One step bioconversion of waste precious metals into Serratia biofilmimmobilized catalyst for Cr(VI) reduction. Biotechnol. Lett. 37, 2181-2191. doi: 10.1007/s10529-015-1894-1

Yong, P., Mikheenko, I. P., Deplanche, K., Redwood, M. D., and Macaskie, L. E. (2010). Biorefining of precious metals from wastes: an answer to manufacturing of cheap nanocatalysts for fuel cells and power generation via an integrated biorefinery? Biotechnol. Lett. 32, 1821-1828. doi: 10.1007/s10529-0100378-6

Zaleska-Medynska, A., Marchelek, M., Diak, M., and Grabowska, E. (2016). Noble metal-based bimetallic nanoparticles: the effect of the structure on the optical, catalytic and photocatalytic properties. Adv. Colloid. Interface Sci. 229, 80-107. doi: 10.1016/j.cis.2015.12.008

Zhu, J. (2014). Synthesis of Precious Metal Nanoparticles Supported on Bacterial Biomass for Catalytic Applications in Chemical Transformations. PhD. Thesis. Birmingham: University of Birmingham.

Zhu, J., Wood, J., Deplanche, K., Mikheenko, I. P., and Macaskie, L. E. (2016). Selective hydrogenation using palladium bioinorganic catalyst. Appl. Catal. B Environ. 199, 108-122. doi: 10.1016/j.apcatb.2016.05.060

Zu, Y. H., Yang, P. P., Wang, J. J., Liu, X. H., Ren, J. W., Lu, G. Z., et al. (2014). Efficient production of the liquid fuel 2, 5-dimethylfuran from 5hydroxymethylfurfural over Ru/Co3O4 catalyst. Appl. Catal. B Environ. 146, 244-248. doi: 10.1016/j.apcatb.2013.04.026

Conflict of Interest Statement: The authors declare that the research was conducted in the absence of any commercial or financial relationships that could be construed as a potential conflict of interest.

Copyright (C) 2019 Gomez-Bolivar, Mikheenko, Orozco, Sharma, Banerjee, Walker, Hand, Merroun and Macaskie. This is an open-access article distributed under the terms of the Creative Commons Attribution License (CC BY). The use, distribution or reproduction in other forums is permitted, provided the original author(s) and the copyright owner(s) are credited and that the original publication in this journal is cited, in accordance with accepted academic practice. No use, distribution or reproduction is permitted which does not comply with these terms. 